\title{
Applications of Nanosheets in Frontier Cellular Research
}

\author{
Wenjing Huang ${ }^{1,2,+}$, Yuta Sunami $1,3, *(\mathbb{D})$, Hiroshi Kimura ${ }^{1,3}$ and Sheng Zhang ${ }^{1,4, *,+(1)}$ \\ 1 Micro/Nano Technology Center, Tokai University, 4-1-1 Kitakaname, Hiratsuka-city, \\ Kanagawa 259-1292, Japan; huang@tsc.u-tokai.ac.jp (W.H.); hkimura@tokai-u.jp (H.K.) \\ 2 Department of Bioengineering, School of Engineering, The University of Tokyo, 7-3-1 Hongo, Bunkyo-ku, \\ Tokyo 113-8656, Japan \\ 3 Department of Mechanical Engineering, Tokai University, 4-1-1 Kitakaname, Hiratsuka-city, \\ Kanagawa 259-1292, Japan \\ 4 Division of Biomedical Engineering, Renal Division, Department of Medicine, Brigham and Women's \\ Hospital, Harvard Medical School, Cambridge, MA 02139, USA \\ * Correspondence: sunami@tokai-u.jp (Y.S.); zhangs@tsc.u-tokai.ac.jp or szhang84@hotmail.com (S.Z.) \\ + These authors contributed equally to this work.
}

Received: 28 May 2018; Accepted: 10 July 2018; Published: 12 July 2018

\begin{abstract}
Several types of nanosheets, such as graphene oxide (GO) nanosheet, molybdenum disulfide $\left(\mathrm{MoS}_{2}\right)$ and poly(L-lactic acid) (PLLA) nanosheets, have been developed and applied in vitro in cellular research over the past decade. Scientists have used nanosheet properties, such as ease of modification and flexibility, to develop new cell/protein sensing/imaging techniques and achieve regulation of specific cell functions. This review is divided into three main parts based on the application being examined: nanosheets as a substrate, nanosheets as a sensitive surface, and nanosheets in regenerative medicine. Furthermore, the applications of nanosheets are discussed, with two subsections in each section, based on their effects on cells and molecules. Finally, the application prospects of nanosheets in cellular research are summarized.
\end{abstract}

Keywords: nanosheet; cell adhesion; drug delivery; cell capturing; regenerative medicine

\section{Introduction}

To date, many fabrication technologies have been developed for different types of nanosheets, such as graphene oxide (GO) nanosheet, molybdenum disulfide $\left(\mathrm{MoS}_{2}\right)$, and poly(L-lactic acid) (PLLA) nanosheets [1-4]. Shortly after the development of the fabrication technology, researchers applied nanosheets to cellular research. Monocrystalline graphitic films a few atoms thick were first reported in 2004, and $\mathrm{MoS}_{2}$ nanosheets were fabricated successfully in 2011 (Liu et al., 2008) [2]. Furthermore, NO nanosheets were applied as carriers of SN38 in 2008-a drug with high cancer cell killing potency-and $\mathrm{MoS}_{2}$ nanosheets were used for the detection of DNA and small molecules due to their fluorescence-quenching ability and DNA affinity [5-7]. Fujie et al. developed fabrication techniques for PLLA nanosheets in 2007, and they investigated the cell adhesion properties of the sheets in $2011[3,8]$. As is known, most nanosheets are transparent and have excellent electrical and thermal properties with a large size-aspect ratio $\left(>10^{6}\right)$. Therefore, the application of nanosheets in relation to cellular research is due to the following properties. (1) The nanosheet surface can be modified (biofunctionalized) relatively easy for applications in cellular research [9-11]. (2) Cells or molecules show functional responses after the interaction with materials of nanosheets [12-14]. (3) Nanosheets are flexible, and cells adhered to the sheets are transplanted without cell detachment [15]. Further, fragments of nanosheets can be endocytosed by cells $[16,17]$. 
Besides GO, $\mathrm{MoS}_{2}$, and PLLA, many other nanosheets or two-dimensional (2D) materials have been newly developed. For example, in 2017, $\pi$-conjugated 2D porous organic nanosheets called NUS-24 were developed, and they showed high sensitivity toward $\mathrm{Fe}^{3+}$ ions and nitro-containing compounds, although their application in cellular research has not been realized [18]. On the other hand, many of the 2D graphene analogues, including $\pi$-conjugated 2D porous organic nanosheets, 2D graphene analogues (such as hexagonal boron nitride ( $\mathrm{h}-\mathrm{BN}$ ), carbon nitride, and transition metal di-chalcogenides), have been developed, and some of them were applied in cellular research [19-21]. Analogues, such as h-BN and monolayer $2 \mathrm{D}$ graphitic carbon nitride $\left(\mathrm{g}-\mathrm{C}_{3} \mathrm{~N}_{4}\right)$ nanosheets, were fabricated and used for cell imaging [19,22]. Further, there are techniques to prepare nanosheets on titanium surfaces for applications in biomedical research $[13,23,24]$. Therefore, nanosheets made from various types of materials have been used in cellular research, which makes their application extensive.

Diverse research on the application of nanosheets promotes the development of new technologies for disease diagnosis/therapy and regenerative medicine at cellular levels [25-29]. This review focuses on the research of cell capturing, regulation of cell adhesion and function, protein delivery into cells/transfection, cellular-level sensing/imaging, and regeneration regulation at cell levels using nanosheets.

\section{Nanosheets as a Substrate}

\subsection{Effects of Nanosheets on Cell Adhesion and Function}

Cell adhesion to nanosheets with various functions was investigated for further applications. Cells adhere to the extracellular matrix (ECM) through transmembrane proteins called integrins, which are a type of focal adhesion protein that serve as the mechanical linkages to the ECM. Substrate conditions, such as coating of extracellular matrix, substrate stiffness, and substrate topology, are important for cell adhesion and growth. A study by Okada et al. suggested that hydroxyapatite (HAp) nanosheet substrates with contact domains larger than $100 \mathrm{~nm}$ were required for the stable adhesion of rat bone marrow-derived mesenchymal stem cells [30]. Da Silva et al. developed an ultrathin flat sheet with controlled wettability using the spontaneous assembly of a peptide bolaamphiphile called $\mathrm{RFL}_{4} \mathrm{FR}$ ( $\mathrm{R}$, arginine; $\mathrm{F}$, phenylalanine; $\mathrm{L}$, leucine). Growth of human corneal stromal fibroblast (hCSF) cells was successful on this type of nanosheet, due to the wettability of the bolaamphiphile peptides resulting from hydrophilic peptide groups at both ends of a long hydrophobic hydrocarbon chain or peptide sequence [31]. The adhesion properties of nanosheets can be modified by the coating of ECM, and the coating method may influence the cell adhesion properties. Poly-L-lactic acid (PLLA) nanosheets possess anti-adhesive properties and can prevent unwanted wound adhesion, therefore, the nanosheets can be used as wound dressing. Niwa et al. showed that spin-coating collagen on the PLLA nanosheet promotes the adhesion of murine fibroblast cell line NIH3T3 [32]. Cell adhesion is also dependent on the stiffness of the underlying substrate: when rat cardiomyocytes were cultured on PLLA nanosheets placed on flat $\mathrm{SiO}_{2}$ substrate and metal meshes, cells showed almost equal distribution on the substrate but adhered specifically to the parts along the metal meshes (Figure 1) [8]. In addition, some novel types of nanosheets are developed specifically for cell culture and tissue engineering. Laurenti et al. developed a magnesium phosphate nanosheet-based thixotropic gel, and osteoblast cells could adhere onto the 2D structures and form colonies [33]. Functionalized nanosheets were also synthesized onto traditional medical materials for improving cell culture. For example, when calcium-containing nanosheets were synthesized onto a sandblasted and acid-etched (SLA) titanium surface, a sustained release of $\mathrm{Ca}^{2+}$ ions was measured, and adhesion/spreading of MC3T3-E1 cells was upregulated [34]. Coating of flower-like calcium phosphate nanosheets onto a titanium surface can also promote cell adhesion and spreading due to its wettability [35].

The adhesion of HaCaT cells-a spontaneously transformed aneuploidy immortal keratinocyte cell line-was realized on the surface of low-viscosity liquids (for example, a fluorinated oil (Novec 7500, $0.77 \mathrm{cSt}$ ) containing the surfactant) by the self-assembly of mechanically strong protein 
nanosheets on a liquid surface (Figure 2) [36]. Cell adhesion and spreading are critical for various cell functions, and enhancing the adhesion of rat bone marrow cells by culturing on nanosheets of titanium alloys resulted in increased osteogenic differentiation [13]. Nanosheets, such as graphene oxide (GO) nanosheets, are used extensively in living systems. Even so, we cannot ignore some toxic effects of nanosheets on cells. Although this type of nanosheet is not cytotoxic, RBL-2H3 cells cultured on the nanosheet may "feel" environment stress, and shedding of plasma membranes (e.g., detection of membrane fragments) was confirmed [37]. Further, disruption of the cell cytoskeleton was observed in A549 lung carcinoma cells cultured on GO nanosheets [38].
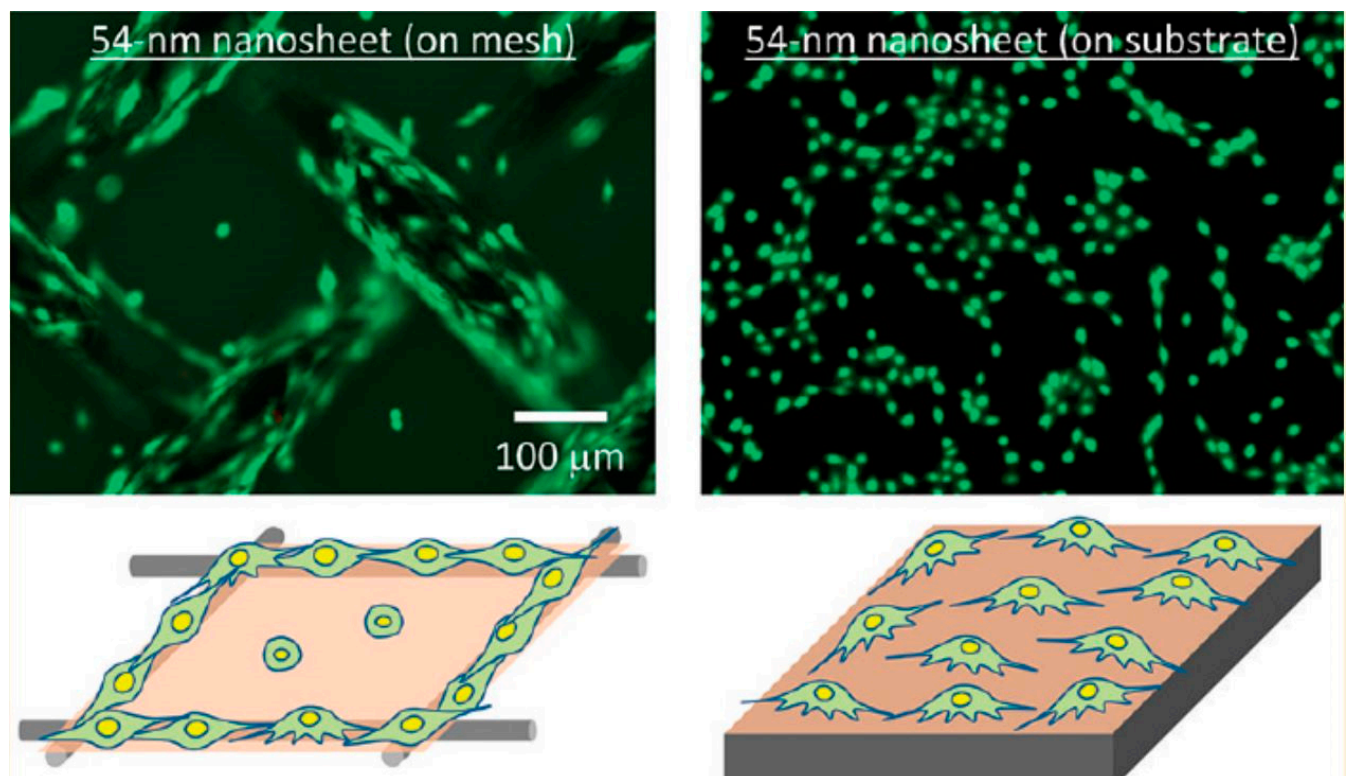

Anisotropic

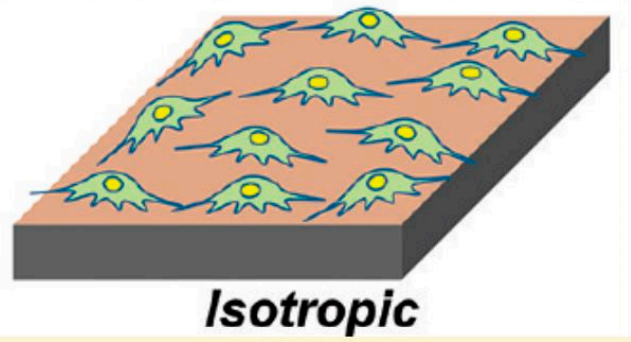

Figure 1. Substrata effect on nano-bio interface [8]. PLLA nanosheets were placed onto a metal substrate or a mesh to evaluate the effects of substrate stiffness on cell adhesion. Most of the H9c2 cells adhered onto the nanosheet part of the metal wire but not the part of the meshed lattice. On the other hand, cells adhered almost evenly across the substrate without differences in stiffness. Reproduced from [8] with permission from American Chemical Society, 2018.

Pan et al. fabricated positively or negatively charged palladium nanosheets by treating the sheets with short chain thiolated carboxylic acids or amines, and they reported that cytotoxic effects may depend on the surface charge. $80 \%$ of HepG2 cells died on the positively charged nanosheets, however, only $30 \%$ died on the negatively charge nanosheets [39]. Molybdenum disulfide $\left(\mathrm{MoS}_{2}\right)$ nanosheets were also reported to disrupt structures of $\alpha$-helical peptides, a common motif in the secondary structure of proteins [40]. On the other hand, scientists are making great efforts to reduce the cytotoxicity. Sasidharan et al. reported that cell apoptosis was observed on as-synthesized graphene because of high oxidative stress, but no toxicity was observed on carboxyl hydrophilic graphene [41]. Likewise, graphene modified with biocompatible polyethylene glycol (PEG) did not show acute toxicity [11,42]. PEGylation decreased the affinity of graphene-based nanomaterials, so, coating nanomaterials with PEG chains was reported as a method to reduce toxicity [43,44]. However, we note that Luo et al. demonstrated that PEGylation could not bypass cytotoxicity, because interactions between PEGylated GO and the membranes of macrophage cells promoted high levels of cytokine secretion through integrin-mediated signaling pathways [45]. As an alternative, GO was functionalized with poly(acrylic acid), and the in vitro and in vivo biocompatibility was found to be superior to PEGylation. The differences in biocompatibility may result from differential compositions of protein 
corona formed on the surface of GO, because the composition may influence their interaction with cell membrane and cellular uptake [46].

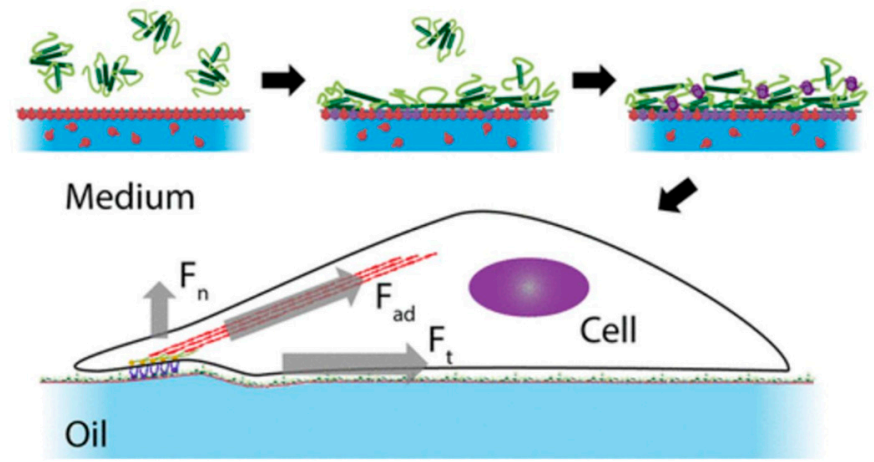

Figure 2. Schematic figure of a cell applying forces across an oil-water interface in the normal and tangential directions. Cell spreading and proliferation are enabled by the protein nanosheets [36]. Forces are presumed to be transmitted from the cell cytoskeleton to the protein nanosheets (extracellular environment) through focal adhesion proteins, and the forces exerted by cells are thought to be counterbalanced by the strength of the protein nanosheets. Reproduced from [8] with permission from American Chemical Society, 2018.

\subsection{Delivery Functions Acted on by Nanosheets}

Various types of nanosheets provide flexible platforms for cell culturing, and the surface-modified nanosheets exhibit excellent drug- or DNA-binding properties. Therefore, nanosheets are naturally used as tools in the delivery of drugs, cell monolayers, and genes. Fujie et al. developed a micropatterned and biodegradable poly(lactic-co-glycolic acid) (PLGA) nanosheet for the delivery of engineered epithelial monolayers into the narrow subretinal space by a simple injection through a syringe needle [25]. Nanosheets with adhered retinal pigmented epithelial cells can withstand deformation in a syringe needle without heavily damaging the cells [25]. This method is impossible for conventional delivery methods, which have used collagen, poly(ethylene terephthalate) (PET), or poly(methyl methacrylate) (PMMA) with sizes of several micrometers to several millimeters as delivery substrates [47-49]. Various structures developed from nanosheets were applied as drug carriers. For example, chitosan-glutathione-valine-valine layered double hydroxides (LDHs) were used to deliver drug to human corneal epithelial primary cells and retinal pigment epithelial cells, and nanosheets with drug (pirenoxine sodium) were uptaken through a cell membrane transporter, peptide transporter-1 (Figure 3) [50]. GO nanosheets were modified by natural peptide protamine sulfate and sodium alginate, and self-assembly of the nanosheets was developed as a drug delivery system. The system possessed properties such as a $\mathrm{pH}$-sensitive release of anticancer drugs and suppression of protein adhesion. Further, the modified GO nanosheets could be uptaken by MCF-7 cells (breast cancer cells) [51]. Delaminated Mg-Al-lactate layered double hydroxide nanosheets were used as vectors to deliver salmon DNA to 293T cells, which was facilitated by the sheets' high DNA adsorption capacity and ability to be uptaken by cells [10]. Black phosphorus (BP) nanosheets were modified with polyethylene glycol amine to improve the loading capacity of theranostic agents such as doxorubicin (DOX) for chemotherapy and cyanine7 (Cy7) for in vivo near-infrared (NIR) imaging [52]. Greek Testudo-like structures were developed from two-dimensional $\mathrm{MoS}_{2}$ nanosheets with DNA oligonucleotides, and the structures responded to heightened ATP metabolism in cancer cells and to released drugs [53].

Conventional transfection processes for cell transfection or gene therapy are complicated, toxic, and less effective, therefore, nanosheets were used as advanced tools for nonviral-based gene delivery substrates. When GO nanosheets formed a complex with cell-penetrating peptides (CPPs), the cytotoxicity of CPPs was mitigated and the transfection efficiency of CPPs with oligonucleotides 
was highly improved [54]. Positively charged $\mathrm{MoS}_{2}$-polyethylene glycol-polyethylenimine nanosheets were loaded with small interfering RNA and added to the cell (HepG2 cell line) culture medium for cell transfection [16]. Unlike the method of adding nanosheets to the cell culture medium (solution-based transfection), Ji et al. developed a silica nanosheet to immobilize the DNA complex, and transfected the cells attached to the nanosheet. The transfection efficiency was approximately $20 \%$ higher than that of solution-based transfection [55]. Further, naked DNA on silica glass without any vectors was transferred into human mesenchymal stem cells, a difficult-to-transfect cell type [56].

A

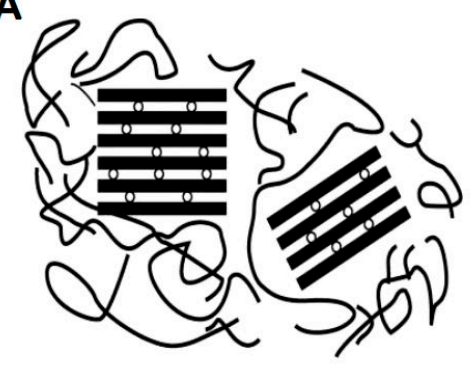

B

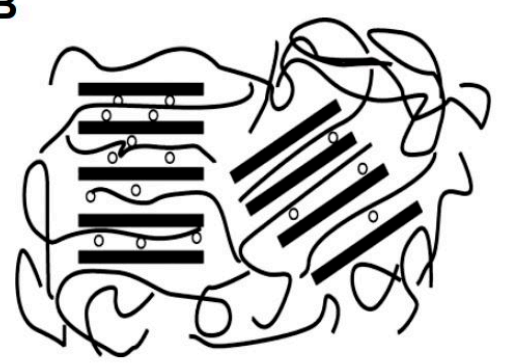

C

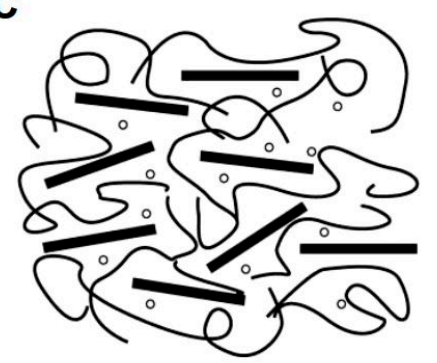

\section{o Drug}
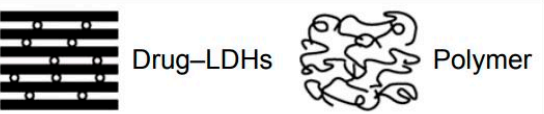

Figure 3. Schematic diagrams of (A) organic-coated inorganic hybrid layered double hydroxide (LDH) nanoparticles; (B) organic-intercalated inorganic hybrid LDH nanoparticles; and (C) organic-inorganic hybrid LDH nanosheets [50]. Reproduced from [50] with permission from Dove Medical Press, 2018.

\section{Nanosheets as a Sensitive Surface}

\subsection{Cell Capturing Using Surface-Modified Nanosheets}

Several technologies have been developed for the capturing of circulating tumor cells, such as microfluidic chips and functionalized and structured medical wire [57-61]. Even so, nanosheets together with other nanomaterials have emerged as effective tools for the isolation of tumor cells [62]. Surface modification of graphene oxide (GO) nanosheets can be easily realized, and GO nanosheets coated with specific antibodies were used as tools for cell capturing. GO nanosheets are carbon-based materials with a benzene basal structure [1]. The structure can interact with the aromatic functional groups of most biomolecules of interest [63]. Since a cell capturing system using three-dimensional microfluidic devices limits cell spreading and further observation on the chip after capturing, Yoon et al. developed GO nanosheet platforms absorbed onto arrayed flat (two-dimensional) gold patterns. The nanosheets were coated with NeutrAvidin, and two human breast cancer cell lines (MCF-7 and Hs-578T) and a human prostate cancer cell line (PC-3) were captured by the interactions between NeutrAvidin and biotinylated EpCAM antibody [64]. In the study by Chen et al., GO nanosheets were coated with single-domain antibody fragments for two different types of white blood cells [65]. Instead of using as-synthesized GO nanosheets, Bardhan et al. improved the nanosheets' function through changing the distribution of oxygen functional groups before coating with an antibody fragment (VHH7), and Class-II MHC-positive cells from murine whole blood were captured quickly and effectively (Figure 4) [63]. 


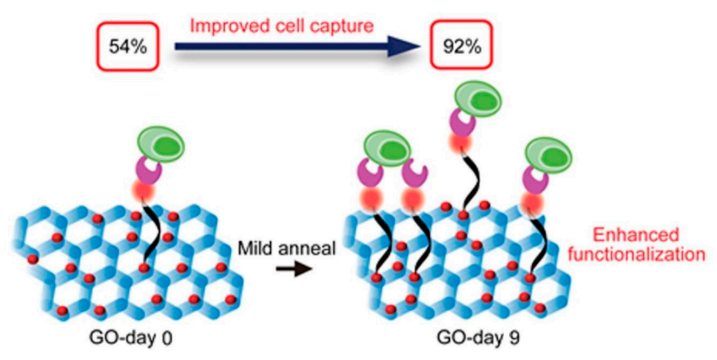

Figure 4. Cell capture improvement by using graphene oxide (GO) nanosheets through oxygen clustering [63]. A mild thermal annealing treatment was used to control and tune the distribution of oxygen functional groups on GO. Reproduced from [63] with permission from American Chemical Society, 2018.

\subsection{Cell Sensing and Imaging}

Nanosheets are used extensively in the fields of sensing and imaging related to cellular research $[9,10,22,26,66-71]$. Cell-signaling sensing using nanosheets will shed new light on essential cell/protein functions. For example, hydrogen peroxide $\left(\mathrm{H}_{2} \mathrm{O}_{2}\right)$ signaling in cells is important, because it is involved in diseases such as Alzheimer's, Parkinson's, and cancer [72-75]. MoS $_{2}$ nanosheets enable the sensing of cell $\mathrm{H}_{2} \mathrm{O}_{2}$ signaling due to their edge sites displaying electrochemical activities [76]. Based on this understanding, Tang et al. developed a three-dimensional nanosheet for the effective sensing of $\mathrm{H}_{2} \mathrm{O}_{2}$ in living RAW 264.7 macrophage cells and neurons on tissue-like three-dimensional structures by exposing abundant nanosheet edge sites [77]. Cytokine tumor necrosis factor (TNF)- $\alpha$ in live cells can be detected by a reduced GO decorated with gold nanoparticles and aryldiazonium salts [78]. A manganese dioxide $\left(\mathrm{MnO}_{2}\right)$ nanosheet-aptamer nanoprobe was fabricated for tumor cell imaging based on a dual-activatable fluorescence/MRI strategy, and the advantages are as follows: (1) Fluorescence signals (aptamers, fluorescein amidate-labeled 7-base DNA) was quenched on the $\mathrm{MnO}_{2}$ nanosheets. After the nanosheets were uptaken by tumor cells, the adsorption of

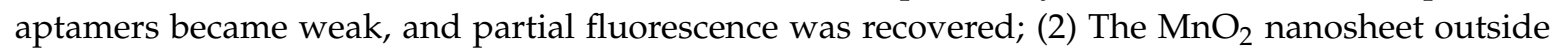
the tumor cells has low $\mathrm{T}_{1}$ - or $\mathrm{T}_{2}$-weighted contrast, and after the nanosheets were uptaken by tumor cells, large amounts of $\mathrm{Mn}^{2+}$ ions were generated for MRI imaging [17]. Similarly, using the fluorescence-quenching ability of GO nanosheets, a platform for the detection of multiple nucleotides was created: the fluorescence was turned "off" by ATP aptamer-FAM and GTP aptamer-Cy5 binding to the GO nanosheet; aptamers were released into cells after the detection of target nucleotides, leading to fluorescence being turned on (fluorescence off/on switch) (Figure 5) [79].

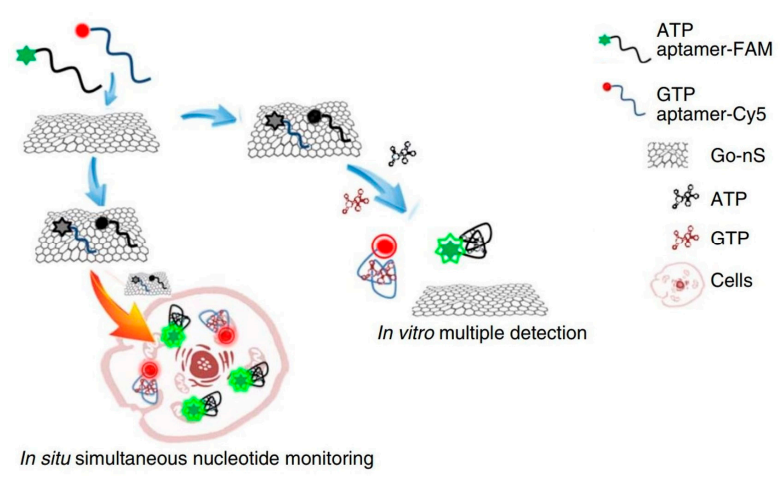

Figure 5. Schematic figure of in vivo and in situ molecular probing in living cells by using the aptamer/GO-nanosheet nanocomplex [79]. When ATP aptamer-FAM and GTP aptamer-Cy5 bind to GO nanosheets, fluorescence is "off" because of the fluorescence-quenching ability of GO. On the other hand, fluorescence is "on" when the aptamers are released into cells. Reproduced from [79] with permission from Nature Publishing Group, 2018. 


\section{Nanosheets in Regenerative Medicine}

\subsection{Nanosheets as a Scaffold Element}

As a scaffold element for tissue regeneration, nanosheets show excellent application features.

Firstly, nanosheets were used to construct three-dimensional structures and endowed the structure with tissue-like anisotropic mechanical properties. A three-dimensional mechanical microenvironment is important for cell differentiation and growth. Liu et al. built up a hydrogel structure with a titanate(IV) nanosheet, and the structure possessed the same anisotropic mechanical properties as articular cartilage. Titanate nanosheets in aqueous colloidal dispersions were exposed to a strong magnetic field, and the nanosheets aligned cofacially. The anisotropic hydrogel structure can withstand compressive forces in the vertical direction, but it is deformable in the horizontal direction (Figure 6) [80]. Nanosheets were used to improve the mechanical properties of scaffolds for cell culturing [81]. For example, Shuai et al. reported that induction of boron nitride nanosheets enhanced the compressive stress of an akermanite scaffold, a promising bioactive material in the field of tissue engineering. In addition, the seeded MG63 osteoblast-like cells and human bone marrow stromal cells adhered and proliferated well [82]. Further, a MoS 2 -akermanite three-dimensional scaffold for tissue regeneration after the removal of tumor tissues was developed using a three-dimensional printing technique [83].

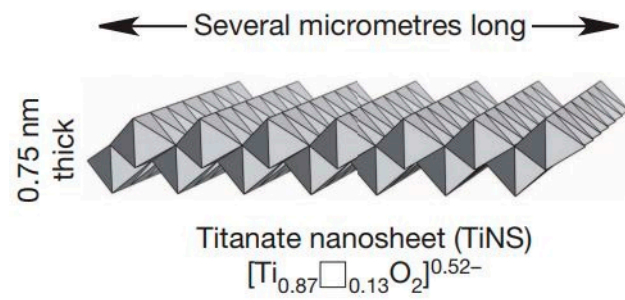

(a)

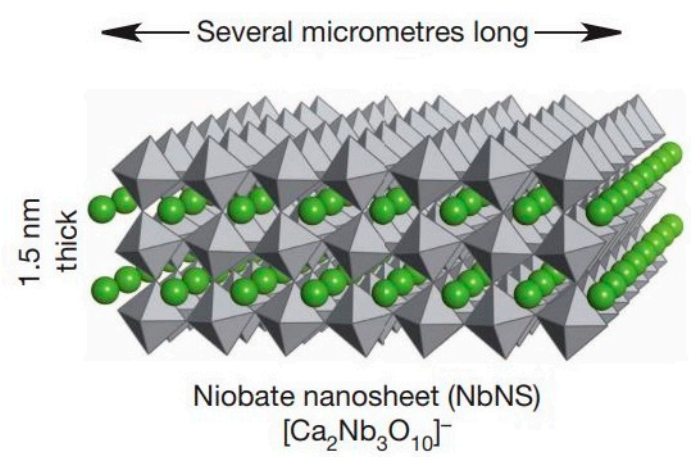

(b)

Figure 6. Schematic figure of negatively charged (a) unilamellar metal oxide nanosheets of titanate (TiNS) and (b) niobate (NbNS) [80]. The cofacially oriented charged nanosheets embedded in hydrogels made the material deform easily when exposed to shear forces while being resilient to compressive forces in the vertical direction. Reproduced from [80] with permission from Nature Publishing Group, 2018.

Secondly, nanosheets are applied as two-dimensional cell sheets. Cell sheets mimic basement membranes. In vivo, the membrane is composed of proteins such as type-IV collagen, laminin, and fibronectin, and has nano-/micropores for cell-cell communication. A porous nanosheets made from a polymer ethyl acetate solution consisting of poly(D,L-lactic acid) and polystyrene. Using the nanosheets, a multilayered structure was created by rolling the nanosheets with adherent $\mathrm{C} 2 \mathrm{C} 12$ myoblasts around a cylinder-shaped template [28].

Thirdly, nanosheets are used as a cell carrier for transplantation into a narrow space. As stated by Suzuki et al., nanosheets, such as a self-assembled monolayer (SAM) of thiol molecules, can be used as a cell carrier without changing the cell-cell contacts during the process of transplantation. A problem is that the SAM is adsorbed onto a gold surface, and scientists have to consider the harvesting method. A negative electrical potential was applied to make the nanosheet with cells to disconnect from the underlying gold surface for transplantation [15]. 


\subsection{Nanosheets for Stem Cell Differentiation and Tissue Regeneration}

Various types of nanosheets have been used for cell differentiation and tissue regeneration at protein and cellular levels. Nanosheets were used in several studies to control the differentiation of stem cells into the desired cell types (the control of stem cell fate), and these studies were reviewed in an article by Kenry et al. [29]. A specific physical and topographical microenvironment resulting from a nanosheet-based platform may regulate stem cell differentiation [84]. GO nanosheets were reported to sustain the self-renewal of mouse embryonic stem cells via a signaling pathway involving integrin [85]. Graphene can also be used to induce the differentiation of mesenchymal stem cells and neural stem cells [86]. Due to the high affinity of insulin resulting from H-bonding and electrostatic interactions, the culture of bone marrow-derived mesenchymal stem cells (MSCs) on GO nanosheets led to adipogenesis [87]. With regard to cell-based tissue regeneration, carbon nitride $\left(\mathrm{C}_{3} \mathrm{~N}_{4}\right)$ nanosheets were used in bone regeneration with the following properties: (1) This carbon nanosheet had a size of less than $200 \mathrm{~nm}$ and low toxicity; (2) The nanosheet can disperse in water easily due to structural polarization (polarized $\mathrm{C}$ and $\mathrm{N}$ atoms) from positive or negative charges. Red light induced a transient photocurrent of $\mathrm{C}_{3} \mathrm{~N}_{4}$ nanosheets, and the photocurrent led to the translocation of $\mathrm{Ca}^{2+}$ and increase in cytosolic $\mathrm{Ca}^{2+}$. Red light absorption of the sheets resulted in human bone marrow-derived mesenchymal stem cells (Figure 7) [88].
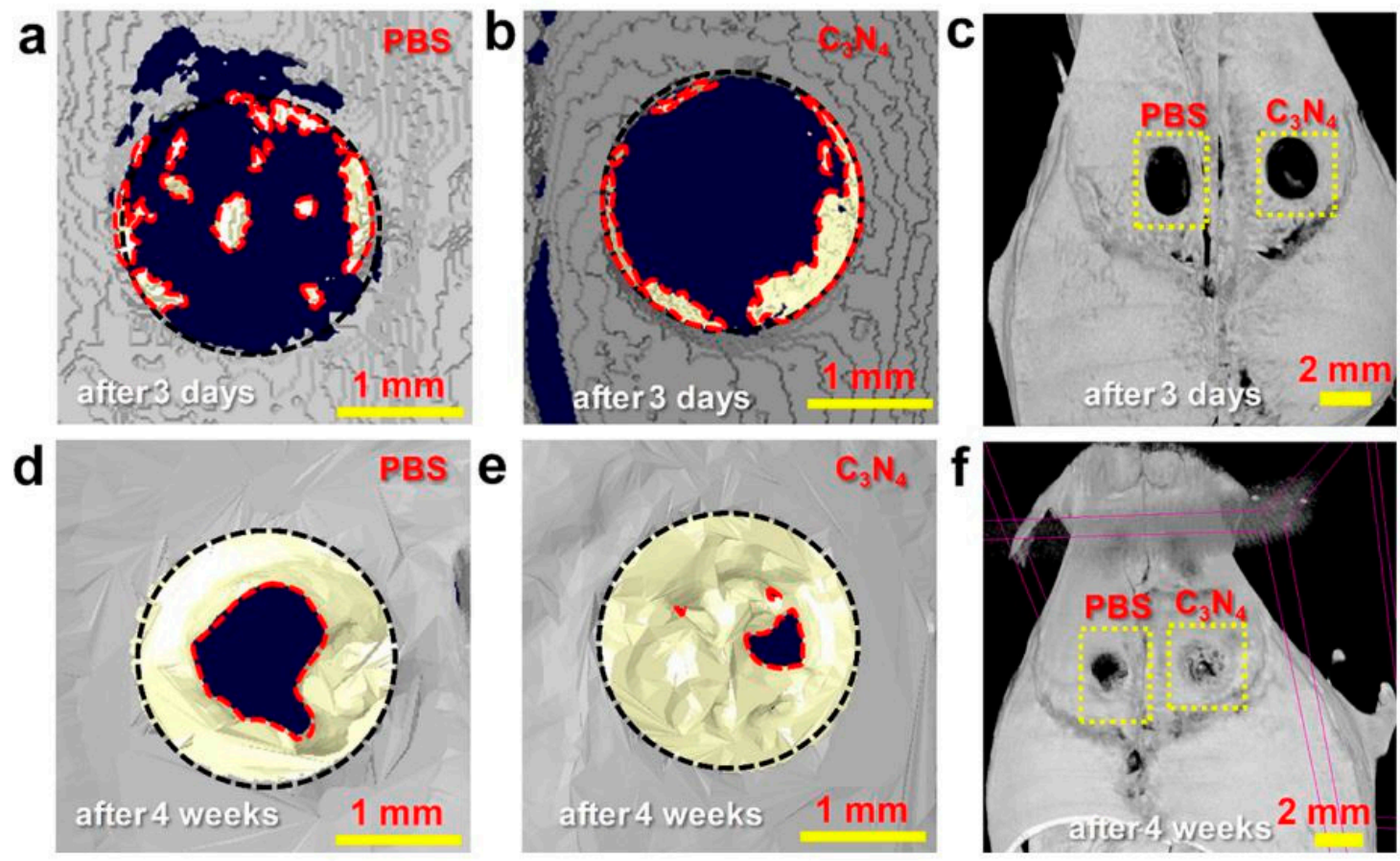

Figure 7. (a-f) Three-dimensional $\mu$-CT images after 3 days or 4 weeks of PBS and $\mathrm{C}_{3} \mathrm{~N}_{4}$ nanosheet-assisted treatment for the enhanced repair of cranial bone defect under red light in vivo [88]. $\mathrm{C}_{3} \mathrm{~N}_{4}$ sheets showed the potential for promoting bone formation. Reproduced from [88] with permission from American Chemical Society, 2018.

\section{Important Issues: Internalization, Distribution, and Cellular Responses}

The above-mentioned studies have shown that cells are capable of internalizing nanosheets, and the internalization and cellular distribution is related not only to the cytotoxicity of nanosheets but also to their potential applications. There are several mechanisms of eukaryotic endocytosis (cell transport of exogenous molecules into the cell), such as clathrin-mediated and caveolae-mediated internalization and macropinocytosis, and the endocytotic mechanism "selected" by cells may depend on the size of the exogenous molecules [89]. The internalization mechanism may depend on types of 
cells and nanosheets, and the distribution of uptaken nanosheets throughout the cell membrane was observed in several organelles. In a study, fluorescein isothiocyanate (FITC)-GO material (PEGylated GO) was added to the culture medium of Sao-2 osteoblasts, MC3T3-E1 preosteoblasts, and RAW 264.7 macrophages seeded on glass coverslips to observe its internalization and distribution. Results showed that internalization of nanosheets depended on the cell type, and FITC-GO molecules were co-localized with F-actin filaments and induced cell-cycle alterations, apoptosis, and oxidative stress [90]. Macropinocytosis was found to be the general mechanism for internalizing FITC-PEG-GOs (ca. 100 $\mathrm{nm}$ ) for human Saos-2 osteoblasts, human HepG2 hepatocytes, and murine RAW 264.7 macrophages, although there may be additional endocytotic mechanism (e.g., clathrin-dependent mechanisms and phagocytosis) for each cell type [91]. Protein (FITC-BSA)-coated GO nanosheets entered cells after surface adhesion for $30 \mathrm{~min}$ and appeared in intracellular vesicles [92]. The internalization processes of few-layer pristine graphene (GR) and monolayer GO flakes by primary cortical neurons were observed in a study by Bramini et al. Exposure to GO, but not GR, reduced the number of excitatory synaptic contacts and altered the $\mathrm{Ca}^{2+}$ dynamics, and a high percentage of $\mathrm{GO}$ flakes were found to enter the lysosome [93]. Similarly, a dual-modal stimulated Raman scattering (SRS)/transient absorption (TA) microscopy technique was developed to observe the distribution of $\mathrm{MoS}_{2}$ nanosheets in live HeLa cells, and it was observed that $\mathrm{MoS}_{2}$ localized with lipid-rich structures, such as endosomes and lysosomes [94]. Further, the nanoassembly of GO/poly(sodium-4-styrenesulfonate) (PLL)/PEGylated PLL can cross the cell membrane, after which it localizes in the lysosomal compartment. Moreover, GO and $\mathrm{TiO}_{2}-\mathrm{GO}$ composites entered A549 cells and localized to the cytoplasm and nucleus [95,96].

As demonstrated by Zhand et al. in a paper discussing the interaction between mammalian cells and graphene materials, the internalization of nanosheets may alter the distribution of intercellular organelles [97]. For example, redistribution of cytoplasmic lactate dehydrogenase (LDH) after exposure to GO and redistribution of mitochondrial cytochrome c in RAW 264.7 cells cultured in a medium with pristine graphene were observed in experiments [98,99]. An interesting observation is that normal and cancer cells may respond differently to nanosheet internalization, and nanosheets have been applied as theranostic materials based on their specific biodistribution and release at the tumor sites and distribution of nanosheets in cancer cells [100,101]. Zhou et al. reported that mitochondrial oxidative phosphorylation (OXPHOS) was impaired in breast cancer cells (MDA-MB-231, MDA-MB-436, and SK-BR-3) by PEG-GO, but OXPHOS in noncancerous cells (MCF-10A) was almost unchanged. A phenomenon like this may be related to the development of a new approach to treating breast cancer [102]. Moreover, compared to normal tissues, tumor tissues have an acidic environment ( $\mathrm{pH}$ value ranging from 4.5 to 5.0 ), and $\mathrm{MnO}_{2}$ nanosheets functionalized with hyaluronic acid (HA) were used to deliver cisplatin (cis-diamminedichloroplatinum (CDDP)) to tumor cells in tumor-bearing animals (mice). These nanosheet-based drug carriers were observed to specifically distribute in the cytoplasm of A549 cancer cells after intracellular uptake and enhance apoptosis of tumor cells $[103,104]$. GO nanosheets may not be effective for the delivery of anticancer drugs, but polyethylene glycol-grafted GO (pGO) combining doxorubicin (DOX) with the photosensitizer chlorin e6 (Ce6) could accumulate in tumor sites over 3 days. This nanosheet-based carrier was distributed in the cytoplasm of SCC7 cells, and disruption of tumor nuclei was observed in tumor sections [105]. $\alpha_{v} \beta_{3}$ integrin was overexpressed on cancer but not normal cells [106]. Using this knowledge, bismuth selenide $\left(\mathrm{Bi}_{2} \mathrm{Se}_{3}\right)$ nanosheets decorated with chitosan and RGD peptide showed the ability to target $\alpha_{\mathrm{V}} \beta_{3}$ integrin on cancer cells, and specific biodistribution of nanosheets was observed to be involved in the suppression of cell growth at tumor sites. Uptake of the $\mathrm{Bi}_{2} \mathrm{Se}_{3}$-chitosan-RGD nanosheets increased prominently in HeLa (cancer) cells, but not in Etc1/E6E7 (normal) cells, resulting in morphological changes of mitochondria and enhanced radiation-induced activation of the p53 signaling pathway involved in cancer cell apoptosis [107]. In a study by Li et al., RAW 264.7 cells (macrophage) were cultured with $\mathrm{Bi}_{2} \mathrm{Se}_{3}$ nanosheets for cellular uptake of the nanosheets, and the macrophages acting as "Trojan horses" (vehicles) were used to transport nanoparticles specifically to tumor tissues [108]. 
For cell internalization of nanosheets, dimension is an important factor. Nanosheets of different sizes have been applied in cellular research. Small nanosheets were used in experiments of cell transfection or protein sensing in live cells. In a study by Mu et al., GO nanosheets were purchased from Cheaptubes.com (Cheap Tubes Inc., Brattleboro, VT, USA), and nanosheets without coating and protein-coated GO nanosheets were investigated using atomic force microscopy. The averaged diameter and height of GO nanosheets was approximately $0.84 \mu \mathrm{m}$ and $1.1 \mathrm{~nm}$, respectively [92]. They found that small nanosheets were uptaken by cells through clathrin-mediated endocytosis (CME), and large nanosheets entered cells through CME and phagocytosis [92]. Simulations by Wang et al. suggested that the degree of oxidation, but not the thickness of graphene, is a crucial factor for cell entry [109]. It has been reported that a large size and a higher oxidization degree may be related to stronger cytotoxicity $[97,110]$.

\section{Cost, Fabrication, and Limitation}

Graphene can be produced from natural graphite (flake graphite and microcrystalline graphite). The recent progress in synthetic strategies of 2D nanosheets were summarized by Yang et al., and approaches to the assembly of 2D nanosheets into 3D architectures were demonstrated by Shen et al. [111,112]. Nowadays, graphene sheets are commercially available [113]. For example, GO can be bought from Aladdin ${ }^{\circledR}$ (Shanghai, China) [85]. According to the price list shown by Cheaptubes.com (Brattleboro, VT, USA), single-layer GO could be purchased at a price of $\$ 400.00-\$ 450.00$ per gram, and the price of few-layer GO is approximately half that. On the other hand, most of the newly developed nanosheets are still commercially unavailable. Graphene is fabricated by several methods, including chemical vapor deposition, micromechanical exfoliation of graphite, and so on [5,114-116]. During the process of chemical vapor deposition, a temperature above $1000{ }^{\circ} \mathrm{C}$ was required [117]. Ping et al. developed a cost-effective method to prepare graphene at a relative low temperature $\left(300{ }^{\circ} \mathrm{C}\right)$ [118]. Further, a spin-coating method was developed to fabricate graphene and metal oxide nanosheets with a size of approximately $30 \mathrm{~mm}$ in $1 \mathrm{~min}$, which also lowers the cost [76]. However, even when the nanosheets are made from the same material, the fabrication processes are important because of cost and biocompatibility evaluation. Kuilla et al. have pointed out that the quality of graphene is an important factor determining its performance [119]. Biological molecules can be adsorbed more easily onto thin graphene nanosheets with fewer layers compared to thicker ones [120]. Small and sharp nanosheets should be internalized easily into cells, and nanomaterials containing impurities may affect the cell uptake mode-of-action and cytotoxicity $[12,120,121]$. Microsized GO induced stronger inflammation responses compared to nanosized GO [121]. In a study by Yue et al., GO was prepared using a modified Hummers method, and the sheets were separated by using specific sedimentation rates, e.g., 100-200 $\mathrm{g}$ and 10,000-30,000 $\mathrm{g}$ centrifugal forces for the separation of the GO nanosheets of $2 \mu \mathrm{m}$ and $350 \mathrm{~nm}$, respectively [121]. Fabrication methods of other types of nanosheets were reviewed by Kurapati et al., and they pointed out that the methods can be summarized as the top-down approach and the bottom-up approach: the former is based on the direct exfoliation of bulk material, and the latter is the process of generating nanosheets via atomic-level control of their composition and structure [122]. In cellular research, nanosheets are not applied as synthesized; additional processes, such as functionalization, modification, and coating, are always necessary (examples shown in Table 1). Further, as mentioned above, an increasing number of nanosheets types are emerging as new biomaterials using conventional medical materials, and these nanosheets could meet specific requirements for applications in cellular research. For example, a nanosheet structure on titanium alloys (Ti6A14V) was formed by a simple $\mathrm{NaOH}$ treatment (alkali etching, $10 \mathrm{M}$ ad. $\mathrm{NaOH}$ treatment at $30^{\circ} \mathrm{C}$ for $24 \mathrm{~h}$ ) [13]. 
Table 1. Application examples of nanosheets in cellular research. PEG: polyethylene glycol; hCSF: human corneal stromal fibroblast; PLGA: poly(lactic-co-glycolic acid); BP: black phosphorus; MSC: marrow-derived mesenchymal stem cell.

\begin{tabular}{|c|c|c|c|c|c|}
\hline & Materials & $\begin{array}{c}\text { Modification/ } \\
\text { Functionalization/FA } \\
\text { Brication }\end{array}$ & Applications & Effectiveness & Ref. \\
\hline \multirow{3}{*}{ Cell adhesion } & $\mathrm{RFL}_{4} \mathrm{FR}$ & - & $\begin{array}{c}\text { Improved } \\
\text { adhesion/growth } \\
\text { of hCSF cells }\end{array}$ & $\begin{array}{l}\text { Wettability } \\
\text { enhancement }\end{array}$ & [31] \\
\hline & PLLA & Collagen coating & $\begin{array}{l}\text { Adhesion of } \\
\text { NIH3T3 cell line }\end{array}$ & & [32] \\
\hline & $\begin{array}{c}\text { Calcium-phosphate } \\
\text { nanosheet + } \\
\text { titanium }\end{array}$ & - & $\begin{array}{l}\text { Improved adhesion } \\
\text { of osteoblast cell }\end{array}$ & $\begin{array}{l}\text { Wettability } \\
\text { enhancement }\end{array}$ & [35] \\
\hline \multirow{3}{*}{ Delivery substrate } & PLGA & $\begin{array}{l}\text { Engineered cell } \\
\text { monolayer on } \\
\text { surface }\end{array}$ & $\begin{array}{c}\text { Injection into } \\
\text { subretinal space } \\
\text { together with cells }\end{array}$ & $\begin{array}{l}\text { Small size; high } \\
\text { flexibility and } \\
\text { biodegradability }\end{array}$ & [25] \\
\hline & $\mathrm{BP}$ & $\begin{array}{l}\text { Modification with } \\
\text { polyethylene } \\
\text { glycol-amine }\end{array}$ & $\begin{array}{l}\text { Drug and dye } \\
\text { carrier }\end{array}$ & $\begin{array}{c}\text { Targeted cancer } \\
\text { therapy }\end{array}$ & [52] \\
\hline & GO & $\begin{array}{l}\text { Cell-penetrating } \\
\text { peptides }\end{array}$ & $\begin{array}{c}\text { Plasmid } \\
\text { transfection into } \\
\text { Hela cells }\end{array}$ & $\begin{array}{l}\text { Cytotoxicity } \\
\text { reduction and } \\
\text { biocompatibility } \\
\text { improvement }\end{array}$ & [54] \\
\hline \multirow{3}{*}{ Cell capturing } & GO & $\begin{array}{c}\text { NeutrAvidin } \\
\text { (cancer-related } \\
\text { biomarker) coating }\end{array}$ & $\begin{array}{l}\text { Capturing of } \\
\text { cancer cells: } \\
\text { MCF-7, Hs-578T, } \\
\text { and PC-3 }\end{array}$ & $\begin{array}{l}\text { Sensitive, } \\
\text { microfluidic-free, } \\
\text { and planar }\end{array}$ & [64] \\
\hline & GO & $\begin{array}{c}\text { A phase } \\
\text { transformation } \\
\text { through oxygen } \\
\text { clustering }\end{array}$ & $\begin{array}{c}\text { Capturing of } \\
\text { Class-II } \\
\text { MHC-positive cells }\end{array}$ & $\begin{array}{c}\text { Sensitive, } \\
\text { microfluidic-free, } \\
\text { and planar }\end{array}$ & [63] \\
\hline & GO & $\begin{array}{l}\text { Coating with VHH7 } \\
\text { and VHH DC } 13\end{array}$ & $\begin{array}{l}\text { Capturing of Class } \\
\text { II MHC-eGFP }{ }^{+} \text {and } \\
\text { CD } 11 b^{+} \text {cells }\end{array}$ & $\begin{array}{l}\text { Effective, rapid, and } \\
\text { microfluidic-free }\end{array}$ & [65] \\
\hline \multirow{3}{*}{$\begin{array}{l}\text { Cell sensing } \\
\text { /imaging }\end{array}$} & $\mathrm{WS}_{2}$ & $\begin{array}{l}\text { Three-dimensional } \\
\text { reconstruction }\end{array}$ & $\begin{array}{l}\text { Sensing of } \mathrm{H}_{2} \mathrm{O}_{2} \text { in } \\
\text { living RAW } 264.7 \\
\text { macrophage cells }\end{array}$ & $\begin{array}{c}\text { Effective in a } \\
\text { three-dimensional } \\
\text { structure }\end{array}$ & [77] \\
\hline & Reduced GO & $\begin{array}{l}\text { Decoration with gold } \\
\text { nanoparticles and } \\
\text { aryldiazonium salts }\end{array}$ & $\begin{array}{l}\text { Sensing of TNF- } \alpha \\
\text { secreted by live } \\
\text { BV-2 cells }\end{array}$ & $\begin{array}{l}\text { High sensitivity and } \\
\text { stability }\end{array}$ & [78] \\
\hline & $\mathrm{MnO}_{2}$ & $\begin{array}{l}\text { In combination with } \\
\text { fluorescent probe }\end{array}$ & $\begin{array}{l}\text { Tumor cell imaging } \\
\text { after cell uptake }\end{array}$ & $\begin{array}{l}\text { Fluorescence off/on } \\
\text { switch }\end{array}$ & [17] \\
\hline \multirow{3}{*}{ Scaffold elements } & $\begin{array}{l}\text { Akermanite }+ \\
\text { boron nitride } \\
\text { nanosheets } \\
\text { (BNNSs) }\end{array}$ & $\begin{array}{c}\text { Fabrication } \\
\text { technique: selective } \\
\text { laser sintering } \\
\text { system }\end{array}$ & $\begin{array}{c}\text { In vivo-like } \\
\text { microenvironment } \\
\text { for MG63 } \\
\text { osteoblast-like cells }\end{array}$ & $\begin{array}{l}\text { Increased } \\
\text { compressive strength } \\
\text { and fracture } \\
\text { toughness }\end{array}$ & [82] \\
\hline & $\begin{array}{l}\text { Polymer ethyl } \\
\text { acetate solution } \\
\text { (poly(D,L-lactic } \\
\text { acid) and } \\
\text { polystyrene) }\end{array}$ & $\begin{array}{c}\text { Fabrication } \\
\text { technique: gravure } \\
\text { coating and } \\
\text { polymer-based phase } \\
\text { separation }\end{array}$ & $\begin{array}{l}\text { Application as a } \\
\text { basement } \\
\text { membrane for the } \\
\text { cell-cell (C2C12 } \\
\text { myoblasts) } \\
\text { communication }\end{array}$ & Porous nanosheets & [28] \\
\hline & PLGA & $\begin{array}{c}\text { Self-assemble } \\
\text { monolayer of } \\
\text { L-cysteine }\end{array}$ & $\begin{array}{l}\text { Transplantation of } \\
\text { cells on PLGA }\end{array}$ & $\begin{array}{l}\text { PLGA detachment } \\
\text { from substrate in } \\
\text { response to a } \\
\text { negative electrical } \\
\text { potential }\end{array}$ & [15] \\
\hline \multirow{2}{*}{$\begin{array}{c}\text { Stem cell } \\
\text { differentiation and } \\
\text { tissue regeneration }\end{array}$} & GO & - & $\begin{array}{l}\text { Sustaining the } \\
\text { self-renewal of } \\
\text { mouse embryonic } \\
\text { stem cells }\end{array}$ & $\begin{array}{l}\text { A signaling pathway } \\
\text { involving integrin }\end{array}$ & [85] \\
\hline & GO & - & $\begin{array}{l}\text { Differentiation of } \\
\text { MSCs to } \\
\text { adipogenesis }\end{array}$ & $\begin{array}{l}\text { High affinity of } \\
\text { insulin resulting } \\
\text { from H-bonding and } \\
\text { electrostatic } \\
\text { interactions }\end{array}$ & [87] \\
\hline
\end{tabular}


Table 1. Cont.

\begin{tabular}{|c|c|c|c|c|c|}
\hline & Materials & $\begin{array}{c}\text { Modification/ } \\
\text { Functionalization/FA } \\
\text { Brication }\end{array}$ & Applications & Effectiveness & Ref. \\
\hline & $\mathrm{C}_{3} \mathrm{~N}_{4}$ nanosheets & - & $\begin{array}{l}\text { Accelerated bone } \\
\text { regeneration }\end{array}$ & $\begin{array}{l}\text { Increase of cytosolic } \\
\mathrm{Ca}^{2+} \text { by } \\
\text { photoinduced charge } \\
\text { transfer }\end{array}$ & [88] \\
\hline \multirow{4}{*}{$\begin{array}{l}\text { Internalization and } \\
\text { redistribution of } \\
\text { nanosheets and } \\
\text { cellular organelles }\end{array}$} & GO & PEGylation + FITC & $\begin{array}{l}\text { Investigation of } \\
\text { cellular } \\
\text { distribution }\end{array}$ & $\begin{array}{l}\text { Co-localization with } \\
\text { F-actin filaments }\end{array}$ & [90] \\
\hline & $\begin{array}{l}\mathrm{GO} \text { or } \mathrm{TiO}_{2}-\mathrm{GO} \\
\text { composite }\end{array}$ & - & $\begin{array}{l}\text { Investigation of } \\
\text { cytotoxicity on } \\
\text { A549 cells }\end{array}$ & $\begin{array}{l}\text { Internalization and } \\
\text { entry into the } \\
\text { cytoplasm and } \\
\text { nucleus }\end{array}$ & [96] \\
\hline & Pristine graphene & - & $\begin{array}{l}\text { Investigation of the } \\
\text { biological effects } \\
\text { on murine RAW } \\
264.7 \text { macrophages }\end{array}$ & $\begin{array}{l}\text { Redistribution of } \\
\text { pro-apoptotic } \\
\text { mitochondrial } \\
\text { factors }\end{array}$ & [99] \\
\hline & GO & PEGylation & $\begin{array}{c}\text { A potential } \\
\text { anti-metastatic } \\
\text { agent }\end{array}$ & $\begin{array}{l}\text { Impairment of } \\
\text { mitochondrial } \\
\text { oxidative } \\
\text { phosphorylation }\end{array}$ & [102] \\
\hline
\end{tabular}

Currently, there are still limitations to the development and application of nanosheets in cellular research. First, isolation of graphene nanosheets was just realized in 2004, and nanosheets have been used in cellular research for only about 10 years. The understanding of cell-nanosheet interaction is limited with respect to the mechanical and electrical properties of nanosheets [29]. As mentioned above, cells may respond to physical factors such as size and oxidative degree through specific functional proteins, and a high concentration of nanosheets may be toxic to cells $[92,110,123]$. Therefore, when a new type of nanosheet is developed, large numbers of pre-experiments on cells may be necessary to optimize the fabrication processes. Without any functional improvement, nanosheets may not only influence cell adhesion and spreading, but also induce previously uncharacterized cellular responses [37], which may result in an inflammatory response. Second, regarding their application as scaffolds in tissue engineering, although there have been many types of nanosheets, few sophisticated techniques have been developed for the induction of nanosheets into a three-dimensional structure as an in vivo-like microenvironment. Cells cultured on a solid flat surface as a monolayer may respond to drugs differently from those in three-dimensional culture models [124]. Interaction of a specific functional group of nanosheet with cells is crucial to the cells' ability to adhere [97]. Although nanosheets have been applied to strengthen the scaffold in tissue engineering, there are no techniques to control the local distribution and alignment of nanosheets within three-dimensional structures. It is expected that there is little diffusion in a solid scaffold, and without precise control of the local distribution, there may be undefined cell-nanosheet interactions. There are still other reasons for precise control. For example, mechanical properties of articular cartilage are different at the surface, middle, and deep layers, and, to regenerate engineered tissue, precise control of mechanical properties is necessary [125]. Further, Bressan et al. pointed out that, because graphene is in the form of a dry powder at some point, there may be a potential health risk through inhalation [86]. Graphene-family nanomaterials may also lead to adsorptive and quenching artifacts in biological assays [86,126].

\section{Conclusions and Perspectives}

Application examples of nanosheets in cellular research are listed in Table 1. This review investigates the effects of several types of nanosheets on cells and the development of fabrication techniques. As a substrate, nanosheets may influence the function of cells, depending on parameters such as the sheet thickness and the mechanical properties of supporting substrate. The surface of nanosheets can be modified to reduce cell cytotoxicity and improve biocompatibility. Coating of 
nanosheets with specific antibodies makes the nanosheets sensitive to targeted cells. Since nanosheets can interact strongly with DNA or drugs and have a fluorescence-quenching ability, these materials have been extensively applied as a delivery carrier and as a substrate for cell sensing and imaging in cellular research. Further, nanosheets are involved in regulation of stem cell differentiation, acting as a scaffold for cellular organization. Based on the above-mentioned applications, it can be concluded that nanosheets have several important advantages as a biomaterial benefiting cellular research: (1) Compared to nanoparticles, nanosheets offer a large surface area for cell adhesion or construction of flat nanoplatforms by the attachment of various functional molecules or even nanoparticles. Further, nanosheets show some excellent properties, such as highly polarized positive and negative charges; (2) Unlike conventional biomaterials, such as Polydimethylsiloxane (PDMS) membranes at the microscale, although the thickness may be several nanometers, nanosheets of different lengths and widths - from several centimeters to several nanometers-are available according to experimental needs. Further, nanosheets of the appropriate size can be internalized by cells, and flexible nanosheets with adhered cells can be transplanted through injection; (3) Because the internalization of nanosheets differs between normal and cancer cells, there is a trend to employ nanosheets in the research of cancer diagnosis and therapy. Layered nanosheets are also capable of enveloping drugs, forming a drug delivery structure. Further, nanosheets may change in form (e.g., curled shape to flat shape) in response to microenvironment conditions, such as $\mathrm{pH}$. Even so, the following will promote the application of nanosheets to cellular research in the future: (1) A deep understanding of interaction of nanosheets with cells through cell membranes is a prerequisite. Although there is also a trend to develop nanosheets with conventional medical materials, it is necessary to improve the biocompatibility of nanosheets by performing sufficient investigations on cytotoxicity on specific cell types and improving fabrication techniques; (2) Technical breakthrough in harvesting of nanosheets is important for the handling and transplanting of cell/nanosheet constructs. Further, delivery and distribution of nanosheets to targeted cells in a three-dimensional structure, or coupling of nanosheets into a three-dimensional structure, is still an important issue; (3) It will be remarkable to develop design theories and the fabrication techniques for the functionalization of large-scale nanosheets with additional functions for cell culture, such as oxygen permeability and porosity.

Author Contributions: S.Z. did most writing for the manuscript and literature studying; W.H. provided the idea and framework; Y.S. and H.K. partially supervised the manuscript process.

Funding: This research was funded by MEXT (Japanese Ministry of Education, Culture, Sports, Science and Technology)-Supported Program for the Strategic Research Foundation at Private Universities, Grant \# S1411010.

Conflicts of Interest: The authors declare no conflict of interest.

\section{References}

1. Li, X.; Zhang, G.; Bai, X.; Sun, X.; Wang, X.; Wang, E.; Dai, H. Highly conducting graphene sheets and Langmuir-Blodgett films. Nat. Nanotechnol. 2008, 3, 538-542. [CrossRef] [PubMed]

2. Coleman, J.N.; Lotya, M.; O’Neill, A.; Bergin, S.D.; King, P.J.; Khan, U.; Young, K.; Gaucher, A.; De, S.; Smith, R.J.; et al. Two-Dimensional Nanosheets Produced by Liquid Exfoliation of Layered Materials. Science 2011, 331, 568-571. [CrossRef] [PubMed]

3. Fujie, T.; Okamura, Y.; Takeoka, S. Ubiquitous Transference of a Free-Standing Polysaccharide Nanosheet with the Development of a Nano-Adhesive Plaster. Adv. Mater. 2007, 19, 3549-3553. [CrossRef]

4. Zhang, S.; Sunami, Y.; Hashimoto, H. Mini Review: Nanosheet Technology towards Biomedical Application. Nanomaterials 2017, 7, 246. [CrossRef] [PubMed]

5. Novoselov, K.S.; Geim, A.K.; Morozov, S.V.; Jiang, D.; Zhang, Y.; Dubonos, S.V.; Grigorieva, I.V.; Firsov, A.A. Electric Field Effect in Atomically Thin Carbon Films. Science 2004, 306, 666-669. [CrossRef] [PubMed]

6. Liu, Z.; Robinson, J.T.; Sun, X.; Dai, H. PEGylated Nano-Graphene Oxide for Delivery of Water Insoluble Cancer Drugs. J. Am. Chem. Soc. 2008, 130, 10876-10877. [CrossRef] [PubMed]

7. Zhu, C.; Zeng, Z.; Li, H.; Li, F.; Fan, C.; Zhang, H. Single-Layer $\mathrm{MoS}_{2}$-Based Nanoprobes for Homogeneous Detection of Biomolecules. J. Am. Chem. Soc. 2013, 135, 5998-6001. [CrossRef] [PubMed] 
8. Fujie, T.; Ricotti, L.; Desii, A.; Menciassi, A.; Dario, P.; Mattoli, V. Evaluation of Substrata Effect on Cell Adhesion Properties Using Freestanding Poly(l-lactic acid) Nanosheets. Langmuir 2011, 27, 13173-13182. [CrossRef] [PubMed]

9. Oudeng, G.; Au, M.; Shi, J.; Wen, C.; Yang, M. One-Step in Situ Detection of miRNA-21 Expression in Single Cancer Cells Based on Biofunctionalized $\mathrm{MoS}_{2}$ Nanosheets. ACS Appl. Mater. Interfaces 2018, 10, 350-360. [CrossRef] [PubMed]

10. Wang, J.; Bao, W.; Umar, A.; Wang, Q.; O’Hare, D.; Wan, Y. Delaminated Layered Double Hydroxide Nanosheets as an Efficient Vector for DNA Delivery. J. Biomed. Nanotechnol. 2016, 12, 922-933. [CrossRef] [PubMed]

11. Berlin, J.M.; Leonard, A.D.; Pham, T.T.; Sano, D.; Marcano, D.C.; Yan, S.; Fiorentino, S.; Milas, Z.L.; Kosynkin, D.V.; Katherine Price, B.; et al. Effective Drug Delivery, in vitro and in vivo, By Carbon-Based Nanovectors Non-Covalently Loaded With Unmodified Paclitaxel. ACS Nano 2010, 4, 4621-4636. [CrossRef] [PubMed]

12. Li, Y.; Yuan, H.; von dem Bussche, A.; Creighton, M.; Hurt, R.H.; Kane, A.B.; Gao, H. Graphene microsheets enter cells through spontaneous membrane penetration at edge asperities and corner sites. Proc. Natl. Acad. Sci. USA 2013, 110, 12295-12300. [CrossRef] [PubMed]

13. Komasa, S.; Kusumoto, T.; Taguchi, Y.; Nishizaki, H.; Sekino, T.; Umeda, M.; Okazaki, J.; Kawazoe, T. Effect of Nanosheet Surface Structure of Titanium Alloys on Cell Differentiation. J. Nanomater. 2014, 2014, 170. [CrossRef]

14. Li, H.; Fierens, K.; Zhang, Z.; Vanparijs, N.; Schuijs, M.J.; Van Steendam, K.; Feiner Gracia, N.; De Rycke, R.; De Beer, T.; De Beuckelaer, A.; et al. Spontaneous Protein Adsorption on Graphene Oxide Nanosheets Allowing Efficient Intracellular Vaccine Protein Delivery. ACS Appl. Mater. Interfaces 2016, 8, 1147-1155. [CrossRef] [PubMed]

15. Suzuki, J.; Nagai, N.; Nishizawa, M.; Abe, T.; Kaji, H. Electrochemical manipulation of cell populations supported by biodegradable polymeric nanosheets for cell transplantation therapy. Biomater. Sci. 2017, 5, 216-222. [CrossRef] [PubMed]

16. Kou, Z.; Wang, X.; Yuan, R.; Chen, H.; Zhi, Q.; Gao, L.; Wang, B.; Guo, Z.; Xue, X.; Cao, W.; et al. A promising gene delivery system developed from PEGylated $\mathrm{MoS}_{2}$ nanosheets for gene therapy. Nanoscale Res. Lett. 2014, 9, 587. [CrossRef] [PubMed]

17. Zhao, Z.; Fan, H.; Zhou, G.; Bai, H.; Liang, H.; Wang, R.; Zhang, X.; Tan, W. Activatable Fluorescence/MRI Bimodal Platform for Tumor Cell Imaging via $\mathrm{MnO}_{2}$ Nanosheet-Aptamer Nanoprobe. J. Am. Chem. Soc. 2014, 136, 11220-11223. [CrossRef] [PubMed]

18. Dong, J.; Zhang, K.; Li, X.; Qian, Y.; Zhu, H.; Yuan, D.; Xu, Q.-H.; Jiang, J.; Zhao, D. Ultrathin two-dimensional porous organic nanosheets with molecular rotors for chemical sensing. Nat. Commun. 2017, 8, 1142. [CrossRef] [PubMed]

19. Liang, Q.; Li, Z.; Bai, Y.; Huang, Z.-H.; Kang, F.; Yang, Q.-H. Reduced-sized monolayer carbon nitride nanosheets for highly improved photoresponse for cell imaging and photocatalysis. Sci. China Mater. 2017, 60, 109-118. [CrossRef]

20. Brent, J.R.; Savjani, N.; O'Brien, P. Synthetic approaches to two-dimensional transition metal dichalcogenide nanosheets. Prog. Mater. Sci. 2017, 89, 411-478. [CrossRef]

21. Sang, X.; Li, X.; Zhao, W.; Dong, J.; Rouleau, C.M.; Geohegan, D.B.; Ding, F.; Xiao, K.; Unocic, R.R. In situ edge engineering in two-dimensional transition metal dichalcogenides. Nat. Commun. 2018, 9, 2051. [CrossRef] [PubMed]

22. Nurunnabi, M.; Nafiujjaman, M.; Lee, S.-J.; Park, I.-K.; Huh, K.M.; Lee, Y.-K. Preparation of ultra-thin hexagonal boron nitride nanoplates for cancer cell imaging and neurotransmitter sensing. Chem. Commun. 2016, 52, 6146-6149. [CrossRef] [PubMed]

23. Xu, K.; Shen, X.; Chen, W.; Mu, C.; Jiang, C.; Zhao, Y.; Cai, K. Nanosheet-pore topographical titanium substrates: A biophysical regulator of the fate of mesenchymal stem cells. J. Mater. Chem. B 2016, 4, 1797-1810. [CrossRef]

24. Komasa, S.; Yingmin, S.; Taguchi, Y.; Yamawaki, I.; Tsutsumi, Y.; Kusumoto, T.; Nishizaki, H.; Miyake, T.; Umeda, M.; Tanaka, M.; et al. Bioactivity of Titanium Surface Nanostructures Following Chemical Processing and Heat Treatment. J. Hard Tissue Biol. 2015, 24, 257-266. [CrossRef] 
25. Fujie, T.; Mori, Y.; Ito, S.; Nishizawa, M.; Bae, H.; Nagai, N.; Onami, H.; Abe, T.; Khademhosseini, A.; Kaji, H. Micropatterned Polymeric Nanosheets for Local Delivery of an Engineered Epithelial Monolayer. Adv. Mater. 2014, 26, 1699-1705. [CrossRef] [PubMed]

26. Sharafeldin, M.; Bishop, G.W.; Bhakta, S.; El-Sawy, A.; Suib, S.L.; Rusling, J.F. $\mathrm{Fe}_{3} \mathrm{O}_{4}$ nanoparticles on graphene oxide sheets for isolation and ultrasensitive amperometric detection of cancer biomarker proteins. Biosens. Bioelectron. 2017, 91, 359-366. [CrossRef] [PubMed]

27. Sabbaghi-Nadooshan, R.; Siasar Karbasaki, M. Diagnosis GLY120 Antigen for the Blood and Breast Cancers Using Graphene Nanosheet. Int. J. Nanosci. Nanotechnol. 2017, 13, 327-333.

28. Suzuki, S.; Nishiwaki, K.; Takeoka, S.; Fujie, T. Large-Scale Fabrication of Porous Polymer Nanosheets for Engineering Hierarchical Cellular Organization. Adv. Mater. Technol. 2016, 1, 1600064. [CrossRef]

29. Lee, W.C.; Loh, K.P.; Lim, C.T. When stem cells meet graphene: Opportunities and challenges in regenerative medicine. Biomaterials 2018, 155, 236-250.

30. Okada, S.; Ito, H.; Nagai, A.; Komotori, J.; Imai, H. Adhesion of osteoblast-like cells on nanostructured hydroxyapatite. Acta Biomater. 2010, 6, 591-597. [CrossRef] [PubMed]

31. Da Silva, E.R.; Walter, M.N.M.; Reza, M.; Castelletto, V.; Ruokolainen, J.; Connon, C.J.; Alves, W.A.; Hamley, I.W. Self-Assembled Arginine-Capped Peptide Bolaamphiphile Nanosheets for Cell Culture and Controlled Wettability Surfaces. Biomacromolecules 2015, 16, 3180-3190. [CrossRef] [PubMed]

32. Niwa, D.; Fujie, T.; Lang, T.; Goda, N.; Takeoka, S. Heterofunctional nanosheet controlling cell adhesion properties by collagen coating. J. Biomater. Appl. 2011, 27, 131-141. [CrossRef] [PubMed]

33. Laurenti, M.; Al Subaie, A.; Abdallah, M.-N.; Cortes, A.R.G.; Ackerman, J.L.; Vali, H.; Basu, K.; Zhang, Y.L.; Murshed, M.; Strandman, S.; et al. Two-Dimensional Magnesium Phosphate Nanosheets Form Highly Thixotropic Gels That Up-Regulate Bone Formation. Nano Lett. 2016, 16, 4779-4787. [CrossRef] [PubMed]

34. Shao, S.-Y.; Ming, P.-P.; Qiu, J.; Yu, Y.-J.; Yang, J.; Chen, J.-X.; Tang, C.-B. Modification of a SLA titanium surface with calcium-containing nanosheets and its effects on osteoblast behavior. RSC Adv. 2017, 7, 6753-6761. [CrossRef]

35. Ma, Q.; Liao, J.; Tian, T.; Zhang, Q.; Cai, X. A potential flower-like coating consisting of calcium-phosphate nanosheets on titanium surface. Chin. Chem. Lett. 2017, 28, 1893-1896. [CrossRef]

36. Kong, D.; Megone, W.; Nguyen, K.D.Q.; Di Cio, S.; Ramstedt, M.; Gautrot, J.E. Protein Nanosheet Mechanics Controls Cell Adhesion and Expansion on Low-Viscosity Liquids. Nano Lett. 2018, 18, 1946-1951. [CrossRef] [PubMed]

37. Sun, C.; Wakefield, D.L.; Han, Y.; Muller, D.A.; Holowka, D.A.; Baird, B.A.; Dichtel, W.R. Graphene Oxide Nanosheets Stimulate Ruffling and Shedding of Mammalian Cell Plasma Membranes. Chem 2016, 1, $273-286$. [CrossRef] [PubMed]

38. Tian, X.; Yang, Z.; Duan, G.; Wu, A.; Gu, Z.; Zhang, L.; Chen, C.; Chai, Z.; Ge, C.; Zhou, R. Graphene Oxide Nanosheets Retard Cellular Migration via Disruption of Actin Cytoskeleton. Small 2016, 13, 1602133. [CrossRef] [PubMed]

39. Pan, Y.-T.; Smith, C.E.; Kwok, K.S.; Chen, J.; Kong, H.; Yang, H. Functionalized ultrathin palladium nanosheets as patches for HepG2 cancer cells. Chem. Commun. 2015, 51, 14171-14174. [CrossRef] [PubMed]

40. Gu, Z.; Li, W.; Hong, L.; Zhou, R. Exploring biological effects of $\mathrm{MoS}_{2}$ nanosheets on native structures of $\alpha$-helical peptides. J. Chem. Phys. 2016, 144, 175103. [CrossRef] [PubMed]

41. Sasidharan, A.; Panchakarla, L.S.; Chandran, P.; Menon, D.; Nair, S.; Rao, C.N.R.; Koyakutty, M. Differential nano-bio interactions and toxicity effects of pristine versus functionalized graphene. Nanoscale 2011, 3, 2461-2464. [CrossRef] [PubMed]

42. Xu, Z.; Zhu, S.; Wang, M.; Li, Y.; Shi, P.; Huang, X. Delivery of Paclitaxel Using PEGylated Graphene Oxide as a Nanocarrier. ACS Appl. Mater. Interfaces 2015, 7, 1355-1363. [CrossRef] [PubMed]

43. Liu, Z.; Davis, C.; Cai, W.; He, L.; Chen, X.; Dai, H. Circulation and long-term fate of functionalized, biocompatible single-walled carbon nanotubes in mice probed by Raman spectroscopy. Proc. Natl. Acad. Sci. USA 2008, 105, 1410-1415. [CrossRef] [PubMed]

44. Sacchetti, C.; Motamedchaboki, K.; Magrini, A.; Palmieri, G.; Mattei, M.; Bernardini, S.; Rosato, N.; Bottini, N.; Bottini, M. Surface Polyethylene Glycol Conformation Influences the Protein Corona of Polyethylene Glycol-Modified Single-Walled Carbon Nanotubes: Potential Implications on Biological Performance. ACS Nano 2013, 7, 1974-1989. [CrossRef] [PubMed] 
45. Luo, N.; Weber, J.K.; Wang, S.; Luan, B.; Yue, H.; Xi, X.; Du, J.; Yang, Z.; Wei, W.; Zhou, R.; et al. PEGylated graphene oxide elicits strong immunological responses despite surface passivation. Nat. Commun. 2017, 8, 14537. [CrossRef] [PubMed]

46. Xu, M.; Zhu, J.; Wang, F.; Xiong, Y.; Wu, Y.; Wang, Q.; Weng, J.; Zhang, Z.; Chen, W.; Liu, S. Improved In Vitro and In Vivo Biocompatibility of Graphene Oxide through Surface Modification: Poly(Acrylic Acid)-Functionalization is Superior to PEGylation. ACS Nano 2016, 10, 3267-3281. [CrossRef] [PubMed]

47. Thumann, G.; Viethen, A.; Gaebler, A.; Walter, P.; Kaempf, S.; Johnen, S.; Salz, A.K. The in vitro and in vivo behaviour of retinal pigment epithelial cells cultured on ultrathin collagen membranes. Biomaterials 2009, 30, 287-294. [CrossRef] [PubMed]

48. Stanzel, B.V.; Liu, Z.; Brinken, R.; Braun, N.; Holz, F.G.; Eter, N. Subretinal Delivery of Ultrathin Rigid-Elastic Cell Carriers Using a Metallic Shooter Instrument and Biodegradable Hydrogel Encapsulation. Investig. Ophthalmol. Vis. Sci. 2012, 53, 490-500. [CrossRef] [PubMed]

49. Tao, S.; Young, C.; Redenti, S.; Zhang, Y.; Klassen, H.; Desai, T.; Young, M.J. Survival, migration and differentiation of retinal progenitor cells transplanted on micro-machined poly(methyl methacrylate) scaffolds to the subretinal space. Lab Chip 2007, 7, 695-701. [CrossRef] [PubMed]

50. Chi, H.; Gu, Y.; Xu, T.; Cao, F. Multifunctional organic-inorganic hybrid nanoparticles and nanosheets based on chitosan derivative and layered double hydroxide: Cellular uptake mechanism and application for topical ocular drug delivery. Int. J. Nanomed. 2017, 12, 1607-1620. [CrossRef] [PubMed]

51. Xie, M.; Zhang, F.; Liu, L.; Zhang, Y.; Li, Y.; Li, H.; Xie, J. Surface modification of graphene oxide nanosheets by protamine sulfate/sodium alginate for anti-cancer drug delivery application. Appl. Surf. Sci. 2018, 440, 853-860. [CrossRef]

52. Tao, W.; Zhu, X.; Yu, X.; Zeng, X.; Xiao, Q.; Zhang, X.; Ji, X.; Wang, X.; Shi, J.; Zhang, H.; et al. Black Phosphorus Nanosheets as a Robust Delivery Platform for Cancer Theranostics. Adv. Mater. 2016, 29, 1603276. [CrossRef] [PubMed]

53. Li, B.L.; Setyawati, M.I.; Chen, L.; Xie, J.; Ariga, K.; Lim, C.-T.; Garaj, S.; Leong, D.T. Directing Assembly and Disassembly of 2D MoS2 Nanosheets with DNA for Drug Delivery. ACS Appl. Mater. Interfaces 2017, 9, 15286-15296. [CrossRef] [PubMed]

54. Dowaidar, M.; Abdelhamid, H.N.; Hällbrink, M.; Zou, X.; Langel, Ü. Graphene oxide nanosheets in complex with cell penetrating peptides for oligonucleotides delivery. Biochim. Biophys. Acta (BBA) Gen. Subj. 2017, 1861, 2334-2341. [CrossRef] [PubMed]

55. Ji, Q.; Yamazaki, T.; Hanagata, N.; Lee, M.V.; Hill, J.P.; Ariga, K. Silica-based gene reverse transfection: An upright nanosheet network for promoted DNA delivery to cells. Chem. Commun. 2012, 48, 8496-8498. [CrossRef] [PubMed]

56. Huang, N.-C.; Ji, Q.; Ariga, K.; Hsu, S.-H. Nanosheet transfection: Effective transfer of naked DNA on silica glass. NPG Asia Mater. 2015, 7, e184. [CrossRef]

57. Nagrath, S.; Sequist, L.V.; Maheswaran, S.; Bell, D.W.; Irimia, D.; Ulkus, L.; Smith, M.R.; Kwak, E.L.; Digumarthy, S.; Muzikansky, A.; et al. Isolation of rare circulating tumour cells in cancer patients by microchip technology. Nature 2007, 450, 1235-1239. [CrossRef] [PubMed]

58. Saucedo-Zeni, N.; Mewes, S.; Niestroj, R.; Gasiorowski, L.; Murawa, D.; Nowaczyk, P.; Tomasi, T.; Weber, E.; Dworacki, G.; Morgenthaler, N.G.; et al. A novel method for the in vivo isolation of circulating tumor cells from peripheral blood of cancer patients using a functionalized and structured medical wire. Int. J. Oncol. 2012, 41, 1241-1250. [PubMed]

59. Asadian-Birjand, M.; Biglione, C.; Bergueiro, J.; Cappelletti, A.; Rahane, C.; Chate, G.; Khandare, J.; Klemke, B.; Strumia Miriam, C.; Calderón, M. Transferrin Decorated Thermoresponsive Nanogels as Magnetic Trap Devices for Circulating Tumor Cells. Macromol. Rapid Commun. 2015, 37, 439-445. [CrossRef] [PubMed]

60. Zheng, X.; Cheung, L.S.-L.; Schroeder, J.A.; Jiang, L.; Zohar, Y. A high-performance microsystem for isolating circulating tumor cells. Lab Chip 2011, 11, 3269-3276. [CrossRef] [PubMed]

61. Ozkumur, E.; Shah, A.M.; Ciciliano, J.C.; Emmink, B.L.; Miyamoto, D.T.; Brachtel, E.; Yu, M.; Chen, P.-I.; Morgan, B.; Trautwein, J.; et al. Inertial Focusing for Tumor Antigen-Dependent and -Independent Sorting of Rare Circulating Tumor Cells. Sci. Transl. Med. 2013, 5, 179ra47. [CrossRef] [PubMed]

62. Yoon, H.J.; Kozminsky, M.; Nagrath, S. Emerging Role of Nanomaterials in Circulating Tumor Cell Isolation and Analysis. ACS Nano 2014, 8, 1995-2017. [CrossRef] [PubMed] 
63. Bardhan, N.M.; Kumar, P.V.; Li, Z.; Ploegh, H.L.; Grossman, J.C.; Belcher, A.M.; Chen, G.-Y. Enhanced Cell Capture on Functionalized Graphene Oxide Nanosheets through Oxygen Clustering. ACS Nano 2017, 11, 1548-1558. [CrossRef] [PubMed]

64. Yoon, H.J.; Kim, T.H.; Zhang, Z.; Azizi, E.; Pham, T.M.; Paoletti, C.; Lin, J.; Ramnath, N.; Wicha, M.S.; Hayes, D.F.; et al. Sensitive capture of circulating tumour cells by functionalized graphene oxide nanosheets. Nat. Nanotechnol. 2013, 8, 735-741. [CrossRef] [PubMed]

65. Chen, G.-Y.; Li, Z.; Theile, C.S.; Bardhan, N.M.; Kumar, P.V.; Duarte, J.N.; Maruyama, T.; Rashidfarrokh, A.; Belcher, A.M.; Ploegh, H.L. Graphene Oxide Nanosheets Modified with Single Domain Antibodies for Rapid and Efficient Capture of Cells. Chemistry 2015, 21, 17178-17183. [CrossRef] [PubMed]

66. Ou, M.; Huang, J.; Yang, X.; Quan, K.; Yang, Y.; Xie, N.; Wang, K. MnO 2 nanosheet mediated “DD-A" FRET binary probes for sensitive detection of intracellular mRNA. Chem. Sci. 2017, 8, 668-673. [CrossRef] [PubMed]

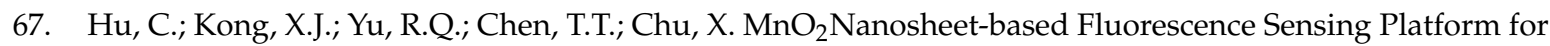
Sensitive Detection of Endonuclease. Anal. Sci. 2017, 33, 783-788. [CrossRef] [PubMed]

68. Tanveer, A.T.; Md Zahidul, I.P.; Hasan, H.; Alma, A.M.R.; Trefa, M.A.; Jacqueline, L.W.; Shaowei, Z. In vitro toxic effects of reduced graphene oxide nanosheets on lung cancer cells. Nanotechnology 2017, 28, 504001.

69. Thirumalraj, B.; Dhenadhayalan, N.; Chen, S.-M.; Liu, Y.-J.; Chen, T.-W.; Liang, P.-H.; Lin, K.-C. Highly sensitive fluorogenic sensing of L-Cysteine in live cells using gelatin-stabilized gold nanoparticles decorated graphene nanosheets. Sens. Actuators B Chem. 2018, 259, 339-346. [CrossRef]

70. Thangasamy, P.; Santhanam, M.; Sathish, M. Supercritical Fluid Facilitated Disintegration of Hexagonal Boron Nitride Nanosheets to Quantum Dots and Its Application in Cells Imaging. ACS Appl. Mater. Interfaces 2016, 8, 18647-18651. [CrossRef] [PubMed]

71. Olivier, G.K.; Cho, A.; Sanii, B.; Connolly, M.D.; Tran, H.; Zuckermann, R.N. Antibody-Mimetic Peptoid Nanosheets for Molecular Recognition. ACS Nano 2013, 7, 9276-9286. [CrossRef] [PubMed]

72. Ohshima, H.; Tatemichi, M.; Sawa, T. Chemical basis of inflammation-induced carcinogenesis. Arch. Biochem. Biophys. 2003, 417, 3-11. [CrossRef]

73. Maruyama, W.; Dostert, P.; Matsubara, K.; Naoi, M. N-methyl(r)salsolinol produces hydroxyl radicals: Involvement to neurotoxicity. Free Radic. Biol. Med. 1995, 19, 67-75. [CrossRef]

74. Amatore, C.; Arbault, S.; Bruce, D.; de Oliveira, P.; Erard, M.; Vuillaume, M. Characterization of the Electrochemical Oxidation of Peroxynitrite: Relevance to Oxidative Stress Bursts Measured at the Single Cell Level. Chem. Eur. J. 2001, 7, 4171-4179. [CrossRef]

75. Miller, E.W.; Albers, A.E.; Pralle, A.; Isacoff, E.Y.; Chang, C.J. Boronate-Based Fluorescent Probes for Imaging Cellular Hydrogen Peroxide. J. Am. Chem. Soc. 2005, 127, 16652-16659. [CrossRef] [PubMed]

76. Bai, J.; Jiang, X. A Facile One-Pot Synthesis of Copper Sulfide-Decorated Reduced Graphene Oxide Composites for Enhanced Detecting of $\mathrm{H}_{2} \mathrm{O}_{2}$ in Biological Environments. Anal. Chem. 2013, 85, 8095-8101. [CrossRef] [PubMed]

77. Tang, J.; Quan, Y.; Zhang, Y.; Jiang, M.; Al-Enizi, A.M.; Kong, B.; An, T.; Wang, W.; Xia, L.; Gong, X.; et al. Three-dimensional $\mathrm{WS}_{2}$ nanosheet networks for $\mathrm{H}_{2} \mathrm{O}_{2}$ produced for cell signaling. Nanoscale 2016, 8 , 5786-5792. [CrossRef] [PubMed]

78. Qi, M.; Zhang, Y.; Cao, C.; Zhang, M.; Liu, S.; Liu, G. Decoration of Reduced Graphene Oxide Nanosheets with Aryldiazonium Salts and Gold Nanoparticles toward a Label-Free Amperometric Immunosensor for Detecting Cytokine Tumor Necrosis Factor- $\alpha$ in Live Cells. Anal. Chem. 2016, 88, 9614-9621. [CrossRef] [PubMed]

79. Wang, Y.; Tang, L.; Li, Z.; Lin, Y.; Li, J. In situ simultaneous monitoring of ATP and GTP using a graphene oxide nanosheet-based sensing platform in living cells. Nat. Protoc. 2014, 9, 1944-1955. [CrossRef] [PubMed]

80. Liu, M.; Ishida, Y.; Ebina, Y.; Sasaki, T.; Hikima, T.; Takata, M.; Aida, T. An anisotropic hydrogel with electrostatic repulsion between cofacially aligned nanosheets. Nature 2014, 517, 68-72. [CrossRef] [PubMed]

81. Zhang, W.; Yu, J.; Chang, H. Two dimensional nanosheets as conductive, flexible elements in biomaterials. J. Mater. Chem. B 2015, 3, 4959-4964. [CrossRef]

82. Shuai, C.; Han, Z.; Feng, P.; Gao, C.; Xiao, T.; Peng, S. Akermanite scaffolds reinforced with boron nitride nanosheets in bone tissue engineering. J. Mater. Sci. Mater. Med. 2015, 26, 188. [CrossRef] [PubMed]

83. Wang, X.; Li, T.; Ma, H.; Zhai, D.; Jiang, C.; Chang, J.; Wang, J.; Wu, C. A 3D-printed scaffold with MoS 2 nanosheets for tumor therapy and tissue regeneration. NPG Asia Mater. 2017, 9, e376. [CrossRef] 
84. Chueng, S.-T.D.; Yang, L.; Zhang, Y.; Lee, K.-B. Multidimensional nanomaterials for the control of stem cell fate. Nano Converg. 2016, 3, 23. [CrossRef] [PubMed]

85. Jing, G.; Wang, Z.; Zhuang, X.; He, X.; Wu, H.; Wang, Q.; Cheng, L.; Liu, Z.; Wang, S.; Zhu, R. Suspended graphene oxide nanosheets maintain the self-renewal of mouse embryonic stem cells via down-regulating the expression of Vinculin. Biomaterials 2018, 171, 1-11. [CrossRef] [PubMed]

86. Bressan, E.; Ferroni, L.; Gardin, C.; Sbricoli, L.; Gobbato, L.; Ludovichetti, F.S.; Tocco, I.; Carraro, A.; Piattelli, A.; Zavan, B. Graphene based scaffolds effects on stem cells commitment. J. Transl. Med. 2014, 12, 296. [CrossRef] [PubMed]

87. Lee, W.C.; Lim, C.H.Y.X.; Shi, H.; Tang, L.A.L.; Wang, Y.; Lim, C.T.; Loh, K.P. Origin of Enhanced Stem Cell Growth and Differentiation on Graphene and Graphene Oxide. ACS Nano 2011, 5, 7334-7341. [CrossRef] [PubMed]

88. Tiwari, J.N.; Seo, Y.-K.; Yoon, T.; Lee, W.G.; Cho, W.J.; Yousuf, M.; Harzandi, A.M.; Kang, D.-S.; Kim, K.-Y.; Suh, P.-G.; et al. Accelerated Bone Regeneration by Two-Photon Photoactivated Carbon Nitride Nanosheets. ACS Nano 2017, 11, 742-751. [CrossRef] [PubMed]

89. Mayor, S.; Pagano, R.E. Pathways of clathrin-independent endocytosis. Nat. Rev. Mol. Cell Biol. 2007, 8, 603-612. [CrossRef] [PubMed]

90. Matesanz, M.-C.; Vila, M.; Feito, M.-J.; Linares, J.; Gonçalves, G.; Vallet-Regi, M.; Marques, P.-A.A.; Portolés, M.-T. The effects of graphene oxide nanosheets localized on F-actin filaments on cell-cycle alterations. Biomaterials 2013, 34, 1562-1569. [CrossRef] [PubMed]

91. Linares, J.; Matesanz, M.C.; Vila, M.; Feito, M.J.; Gonçalves, G.; Vallet-Regí, M.; Marques, P.-A.A.; Portolés, M.T. Endocytic Mechanisms of Graphene Oxide Nanosheets in Osteoblasts, Hepatocytes and Macrophages. ACS Appl. Mater. Interfaces 2014, 6, 13697-13706. [CrossRef] [PubMed]

92. Mu, Q.; Su, G.; Li, L.; Gilbertson, B.O.; Yu, L.H.; Zhang, Q.; Sun, Y.-P.; Yan, B. Size-Dependent Cell Uptake of Protein-Coated Graphene Oxide Nanosheets. ACS Appl. Mater. Interfaces 2012, 4, 2259-2266. [CrossRef] [PubMed]

93. Bramini, M.; Sacchetti, S.; Armirotti, A.; Rocchi, A.; Vázquez, E.; León Castellanos, V.; Bandiera, T.; Cesca, F.; Benfenati, F. Graphene Oxide Nanosheets Disrupt Lipid Composition, $\mathrm{Ca}^{2+}$ Homeostasis, and Synaptic Transmission in Primary Cortical Neurons. ACS Nano 2016, 10, 7154-7171. [CrossRef] [PubMed]

94. Zhang, L.; Shen, S.; Liu, Z.; Ji, M. Label-Free, Quantitative Imaging of $\mathrm{MoS}_{2}$-Nanosheets in Live Cells with Simultaneous Stimulated Raman Scattering and Transient Absorption Microscopy. Adv. Biosyst. 2017, 1, 1700013. [CrossRef]

95. Li, Y.; Lu, Z.; Li, Z.; Nie, G.; Fang, Y. Cellular uptake and distribution of graphene oxide coated with layer-by-layer assembled polyelectrolytes. J. Nanopart. Res. 2014, 16, 2384. [CrossRef]

96. Jin, C.; Wang, F.; Tang, Y.; Zhang, X.; Wang, J.; Yang, Y. Distribution of Graphene Oxide and $\mathrm{TiO}_{2}-\mathrm{Graphene}$ Oxide Composite in A549 Cells. Biol. Trace Elem. Res. 2014, 159, 393-398. [CrossRef] [PubMed]

97. Zhang, B.; Wei, P.; Zhou, Z.; Wei, T. Interactions of graphene with mammalian cells: Molecular mechanisms and biomedical insights. Adv. Drug Deliv. Rev. 2016, 105, 145-162. [CrossRef] [PubMed]

98. Li, Y.; Wu, Q.; Zhao, Y.; Bai, Y.; Chen, P.; Xia, T.; Wang, D. Response of MicroRNAs to In Vitro Treatment with Graphene Oxide. ACS Nano 2014, 8, 2100-2110. [CrossRef] [PubMed]

99. Li, Y.; Liu, Y.; Fu, Y.; Wei, T.; Le Guyader, L.; Gao, G.; Liu, R.-S.; Chang, Y.-Z.; Chen, C. The triggering of apoptosis in macrophages by pristine graphene through the MAPK and TGF-beta signaling pathways. Biomaterials 2012, 33, 402-411. [CrossRef] [PubMed]

100. Zhang, X.-D.; Chen, J.; Min, Y.; Park Gyeong, B.; Shen, X.; Song, S.-S.; Sun, Y.-M.; Wang, H.; Long, W.; Xie, J.; et al. Metabolizable $\mathrm{Bi}_{2} \mathrm{Se}_{3}$ Nanoplates: Biodistribution, Toxicity, and Uses for Cancer Radiation Therapy and Imaging. Adv. Funct. Mater. 2013, 24, 1718-1729. [CrossRef]

101. Yin, F.; Hu, K.; Chen, Y.; Yu, M.; Wang, D.; Wang, Q.; Yong, K.-T.; Lu, F.; Liang, Y.; Li, Z. SiRNA Delivery with PEGylated Graphene Oxide Nanosheets for Combined Photothermal and Genetherapy for Pancreatic Cancer. Theranostics 2017, 7, 1133-1148. [CrossRef] [PubMed]

102. Zhou, T.; Zhang, B.; Wei, P.; Du, Y.; Zhou, H.; Yu, M.; Yan, L.; Zhang, W.; Nie, G.; Chen, C.; et al. Energy metabolism analysis reveals the mechanism of inhibition of breast cancer cell metastasis by PEG-modified graphene oxide nanosheets. Biomaterials 2014, 35, 9833-9843. [CrossRef] [PubMed]

103. Gerweck, L.E.; Seetharaman, K. Cellular pH Gradient in Tumor versus Normal Tissue: Potential Exploitation for the Treatment of Cancer. Cancer Res. 1996, 56, 1194-1198. [PubMed] 
104. Hao, Y.; Wang, L.; Zhang, B.; Li, D.; Meng, D.; Shi, J.; Zhang, H.; Zhang, Z.; Zhang, Y. Manganese dioxide nanosheets-based redox/pH-responsive drug delivery system for cancer theranostic application. Int. J. Nanomed. 2016, 11, 1759-1778.

105. Miao, W.; Shim, G.; Lee, S.; Lee, S.; Choe, Y.S.; Oh, Y.-K. Safety and tumor tissue accumulation of pegylated graphene oxide nanosheets for co-delivery of anticancer drug and photosensitizer. Biomaterials 2013, 34 , 3402-3410. [CrossRef] [PubMed]

106. Desgrosellier, J.S.; Cheresh, D.A. Integrins in cancer: Biological implications and therapeutic opportunities. Nat. Rev. Cancer 2010, 10, 9-22. [CrossRef] [PubMed]

107. Song, Z.; Chang, Y.; Xie, H.; Yu, X.-F.; Chu, P.K.; Chen, T. Decorated ultrathin bismuth selenide nanosheets as targeted theranostic agents for in vivo imaging guided cancer radiation therapy. NPG Asia Mater. 2017, 9, e439. [CrossRef]

108. Li, Z.; Shao, J.; Luo, Q.; Yu, X.-F.; Xie, H.; Fu, H.; Tang, S.; Wang, H.; Han, G.; Chu, P.K. Cell-borne 2D nanomaterials for efficient cancer targeting and photothermal therapy. Biomaterials 2017, 133, 37-48. [CrossRef] [PubMed]

109. Wang, J.; Wei, Y.; Shi, X.; Gao, H. Cellular entry of graphene nanosheets: The role of thickness, oxidation and surface adsorption. RSC Adv. 2013, 3, 15776-15782. [CrossRef]

110. Mao, J.; Guo, R.T.; Yan, L. Simulation and analysis of cellular internalization pathways and membrane perturbation for graphene nanosheets. Biomaterials 2014, 35, 6069-6077. [CrossRef] [PubMed]

111. Yang, W.; Zhang, X.; Xie, Y. Advances and challenges in chemistry of two-dimensional nanosheets. Nano Today 2016, 11, 793-816. [CrossRef]

112. Shen, J.; Zhu, Y.; Jiang, H.; Li, C. 2D nanosheets-based novel architectures: Synthesis, assembly, and applications. Nano Today 2016, 11, 483-520. [CrossRef]

113. Xie, W.; Zhu, X.; Xu, S.; Yi, S.; Guo, Z.; Kuang, J.; Deng, Y. Cost-effective fabrication of graphene-like nanosheets from natural microcrystalline graphite minerals by liquid oxidation-reduction method. RSC Adv. 2017, 7, 32008-32019. [CrossRef]

114. Kim, K.S.; Zhao, Y.; Jang, H.; Lee, S.Y.; Kim, J.M.; Kim, K.S.; Ahn, J.-H.; Kim, P.; Choi, J.-Y.; Hong, B.H. Large-scale pattern growth of graphene films for stretchable transparent electrodes. Nature 2009, 457, 706-710. [CrossRef] [PubMed]

115. Tetlow, H.; Posthuma de Boer, J.; Ford, I.J.; Vvedensky, D.D.; Coraux, J.; Kantorovich, L. Growth of epitaxial graphene: Theory and experiment. Phys. Rep. 2014, 542, 195-295. [CrossRef]

116. McAllister, M.J.; Li, J.-L.; Adamson, D.H.; Schniepp, H.C.; Abdala, A.A.; Liu, J.; Herrera-Alonso, M.; Milius, D.L.; Car, R.; Prud'homme, R.K.; et al. Single Sheet Functionalized Graphene by Oxidation and Thermal Expansion of Graphite. Chem. Mater. 2007, 19, 4396-4404. [CrossRef]

117. Faggio, G.; Capasso, A.; Messina, G.; Santangelo, S.; Dikonimos, T.; Gagliardi, S.; Giorgi, R.; Morandi, V.; Ortolani, L.; Lisi, N. High-Temperature Growth of Graphene Films on Copper Foils by Ethanol Chemical Vapor Deposition. J. Phys. Chem. C 2013, 117, 21569-21576. [CrossRef]

118. Ping, G.; Zhang, J.; Cheng, J.; Shi, L. Graphene nanosheets prepared by low-temperature exfoliation and reduction technique toward fabrication of high-performance poly(1-butene)/graphene films. Iran. Polym. J. 2017, 26, 55-69. [CrossRef]

119. Kuilla, T.; Bhadra, S.; Yao, D.; Kim, N.H.; Bose, S.; Lee, J.H. Recent advances in graphene based polymer composites. Prog. Polym. Sci. 2010, 35, 1350-1375. [CrossRef]

120. Guo, X.; Mei, N. Assessment of the toxic potential of graphene family nanomaterials. J. Food Drug Anal. 2014, 22, 105-115. [CrossRef] [PubMed]

121. Yue, H.; Wei, W.; Yue, Z.; Wang, B.; Luo, N.; Gao, Y.; Ma, D.; Ma, G.; Su, Z. The role of the lateral dimension of graphene oxide in the regulation of cellular responses. Biomaterials 2012, 33, 4013-4021. [CrossRef] [PubMed]

122. Kurapati, R.; Kostarelos, K.; Prato, M.; Bianco, A. Biomedical Uses for 2D Materials Beyond Graphene: Current Advances and Challenges Ahead. Adv. Mater. 2016, 28, 6052-6074. [CrossRef] [PubMed]

123. Meng, S.; Peng, R. Growth and Follow-Up of Primary Cortical Neuron Cells on Nonfunctionalized Graphene Nanosheet Film. J. Appl. Biomater. Funct. Mater. 2016, 14, 26-34. [CrossRef] [PubMed]

124. Antoni, D.; Burckel, H.; Josset, E.; Noel, G. Three-Dimensional Cell Culture: A Breakthrough in Vivo. Int. J. Mol. Sci. 2015, 16, 5517-5527. [CrossRef] [PubMed] 
125. Zhang, L.; Hu, J.; Athanasiou, K.A. The Role of Tissue Engineering in Articular Cartilage Repair and Regeneration. Crit. Rev. Biomed. Eng. 2009, 37, 1-57. [CrossRef] [PubMed]

126. Nel, A.E.; Madler, L.; Velegol, D.; Xia, T.; Hoek, E.M.; Somasundaran, P.; Klaessig, F.; Castranova, V.; Thompson, M. Understanding biophysicochemical interactions at the nano-bio interface. Nat. Mater. 2009, 8, 543-557. [CrossRef] [PubMed] 